\title{
Tumultos, motines y conspiraciones. Una aproximación a la política en armas en Montevideo entre fines del orden colonial y la invasión lusitana ${ }^{1}$
} \author{
Lusitanian invasion \\ Pablo Ferreira \\ Universidad de la República, Uruguay \\ https://orcid.org/0000-0002-0170-5366
}

Tumults, riots and conspiracies. An approach to the politics of arms in Montevideo between the end of the colonial order and the

DOI: https://doi.org/10.25032/crh.v6i11.3

Recibido: $30 / 9 / 2020$

Aceptado: $21 / 11 / 2020$

Resumen. El artículo propone una reflexión sobre la conformación en la ciudad de Montevideo, entre los años finales del orden colonial, la crisis revolucionaria y la invasión lusitana a la Provincia Oriental, de una tradición de acción contestataria que tuvo a los cuerpos milicianos como lugar de acción política y a los motines, tumultos y conspiraciones como formas específicas de incidencia en la toma de decisiones. Busca dar visibilidad a una tradición de acciones colectivas escasamente abordada por la historiografía local y propone una mirada de conjunto que permita avanzar en el conocimiento de estas formas de hacer política. Se busca avanzar respecto a las características comunes que tuvieron estas movilizaciones, las motivaciones invocadas por sus protagonistas, los liderazgos y las fronteras con otros espacios de la política urbana.

Palabras clave: Montevideo; Política; Milicias; Motines; Conspiraciones

Abstract. The article proposes a reflection about the formation in the city of Montevideo, between the/ final years of the colonial order, the revolutionary crisis and the Lusitanian invasion of the Oriental Province, of a tradition of oppositional action that had the militia corps as a place of action politics and tumults, riots and conspiracies as specific forms of

\footnotetext{
${ }^{1}$ Las reflexiones que se plantean en este artículo tienen su origen en la investigación doctoral realizada por el autor entre 2014 y 2020 en el Programa de Doctorado en Historia de la Facultad de Humanidades y Ciencias de la Educación, bajo la dirección de la Dra. Ana Frega. Para la realización de esa investigación conté con una beca de apoyo a docentes de la Comisión Académica de Posgrados de la Universidad de la República.
} 
influence in decision-making. It seeks to give visibility to a tradition of collective actions barely addressed by local historiography and proposes an overview that allows progress in the knowledge of these forms of doing politics. It seeks to advance with respect to the common characteristics that these mobilizations had, the motivations invoked by their protagonists, the leaderships and the borders with other spaces of urban policy.

Keywords: Montevideo; Politics; Militia corps; Riots; Conspiracies

\section{Introducción}

Tras un largo y penoso asedio, el 20 de junio de 1814 las autoridades montevideanas acordaban la capitulación de la ciudad ante los ejércitos del Directorio de las Provincias Unidas del Río de la Plata. Las propuestas emanadas de las negociaciones con los sitiadores se discutieron en la esfera de gobierno de la ciudad, siendo evaluadas por el capitán general Gaspar de Vigodet, los principales jefes de las tropas veteranas y de la Armada, así como por los integrantes del Cabildo. Sin embargo, esa noche en la ciudad no todos estaban de acuerdo con la capitulación. Varios cuerpos milicianos, acuartelados hacía más de un mes en la iglesia Matriz, se amotinaron y tomaron control del recinto. Se oponían a la rendición, acusaban de «traición» a las autoridades y reclamaban por la reducción en las raciones y el atraso en los pagos.

El llamado «motín de la Matriz» fue disuelto tras una mediación encabezada por el sargento mayor de la ciudad y ante la presencia amenazante de las tropas veteranas. Fue reflejo de la efervescencia de una vida política que logró, en la coyuntura dramática que por entonces vivía la ciudad, expresarse de formas diversas. Los protagonistas actuaron siguiendo impulsos variados: para algunos la necesidad de consignar una disconformidad respecto a las decisiones de las autoridades; para otros, una oportunidad de expresar la exaltación de los estados de ánimo en una coyuntura límite. También es posible que se estuvieran poniendo en juego posiciones de poder en la plaza. Lo que resulta claro es que el motín no fue un hecho aislado, sino que coronó una espiral de movilizaciones que se había gestado en los últimos meses. ${ }^{2}$ Era expresión de un «repertorio de acción contestataria» de base local y con evidentes nexos con las formas de hacer política en el espacio atlántico (Tilly, 2002).

\footnotetext{
${ }^{2}$ Este episodio será desarrollado en el cuerpo del artículo. Sobre el mismo véase Ferreira, Pablo «La rendición de Montevideo y el motín de la Matriz en junio de 1814» en Frega, Ana (Coord.), La vida política en Montevideo: elites y sectores populares en tiempos de revolución (Montevideo, CSIC, Universidad de la República, 2018), 45-75.
} 
El artículo que aquí se presenta propone una reflexión sobre la generación en Montevideo, entre la crisis revolucionaria y la ocupación lusitana de la ciudad, de un conjunto de prácticas contestatarias que tuvieron a los cuerpos milicianos como uno de los lugares de acción política, y a los tumultos, motines y conspiraciones como formas específicas de incidencia en la toma de decisiones. 3 Pretende establecer un diálogo con los avances logrados por la historiografía que aborda procesos análogos en el espacio atlántico y específicamente con la producción en la región.

Los cuerpos milicianos fueron un tipo de «fuerza armada no militar» que tuvo variadas formas organizativas y denominaciones a lo largo de Iberoamérica (Chust y Serrano 2007:4). Formaron parte de la organización defensiva colonial, se incorporaron al proceso revolucionario y ocuparon luego, a partir de experiencias como las guardias nacionales, un lugar destacado en la vida política del siglo XIX. Bajo tal denominación se formaron contingentes diversos que tuvieron como principal elemento de identidad su diferenciación respecto al ejército regular, siendo concebidas como cuerpos integrados por vecinos alistados para la defensa de ciudades, pueblos o partidos rurales (Fradkin 2009: 12). La adscripción a la milicia podía ser activa, en el caso de los vecinos varones que realizaban un servicio estacional y de variable duración, o pasiva, en la que se incluían quienes no se hallaban en actividad, por minusvalía física, por excepciones como las que se hicieron (en algunos períodos y lugares) a los comerciantes o porque se había cumplido con la carga del servicio (Cansanello 55). Los milicianos activos debían hacer ejercicios disciplinares que incluían la preparación en el uso de las armas, tenían a su cargo patrullas nocturnas y guardias en distintos puntos del centro urbano y, en casos extraordinarios, podían quedar a disposición para entrar en combate en defensa de la ciudad. En algunos casos podía estar estipulado el cobro de prest, una especie de viático por las jornadas en servicio.

Como ha señalado la historiadora Hilda Sabato (2010: 60), las milicias representaron el principio de la «ciudadanía en armas», es decir, el derecho y el deber que tenían los integrantes de la comunidad política de participar en la defensa de la república. Este principio se constituyó en un terreno abonado por la tradición colonial y las ideas del reformismo ilustrado de la segunda mitad del siglo XVIII, adquiriendo renovados sentidos y legitimidades a partir de las guerras de independencia (Morelli 417). Asimismo, el carácter

\footnotetext{
${ }^{3}$ Hablamos de prácticas contestatarias en tanto acciones colectivas orientadas a la puesta en discusión de las decisiones emanadas de las autoridades inmediatas. No tomamos en cuenta para este calificativo la posición de los sujetos en el escenario más amplio de disputa entre revolución y contrarrevolución que englobaba al espacio atlántico a inicios del siglo XIX.
} 
territorial de la convocatoria (urbana, rural, departamental) fue un elemento que dio continuidad a la institución.

El texto lo hemos estructurado en cuatro partes. En la primera se desarrolla un somero estado del arte en que se dialoga con la producción reciente, destacando algunos de los principales ejes de debate y controversias. En la segunda, se describen los principales tipos de contingentes milicianos surgidos durante el período en la ciudad de Montevideo, resaltando los cambios y continuidades entre la etapa colonial y la fase revolucionaria. En la tercera se analiza un ciclo de tumultos, motines y conspiraciones, de diverso signo político y enmarcados en coyunturas diversas, que mostraron la importancia de la milicia como lugar de la política en Montevideo. En la última parte se trabajan características comunes de estas movilizaciones, las motivaciones invocadas por sus protagonistas, el diálogo con otros espacios de la política urbana, al tiempo que se propone una reflexión respecto al papel de tales contingentes en la vida política del período.

\section{Milicias y política}

La historiografía que aborda el papel político de los cuerpos milicianos entre la crisis del Antiguo Régimen y los procesos de construcción estatal en el siglo XIX se ha venido ampliando considerablemente en las últimas décadas. José Ruiz Ibáñez, en la introducción a una de las mejores compilaciones sobre la temática, ha señalado que durante mucho tiempo tales contingentes tuvieron un reducido protagonismo en los estudios sobre la formación del estado moderno. Los trabajos sobre milicias solían quedar relegados a un rol secundario en estudios de historia militar o en obras de historia local, preocupados en destacar los aspectos pintorescos y el anecdotario asociado al servicio. La renovación en la historia política y militar ha contribuido a ubicar a las milicias como un elemento central para el «ejercicio, reproducción y construcción del poder y el orden social» entre la Época Moderna y el primer siglo de la contemporaneidad (2009: 9-13).

En la historiografía francesa, la Garde Nationale - principal contingente miliciano surgido con la revolución - ha sido poco estudiada y, según Roger Dupuy (2016: 17), sin establecer los puentes necesarios con las experiencias anteriores. En tanto institución heredera de las milicias burguesas del Antiguo Régimen, estuvo ligada a la protección de bienes y personas contra la violencia generada por el desborde de las clases populares o los golpes de fuerza de los estamentos privilegiados. Al mismo tiempo, tuvo la función de defender por las armas las ideas y los logros políticos del tercer estado revolucionario (Girard, 1964). En esa línea, Georges Carrot (2001) estudió la institución analizando lo que denomina 
como sus «mutaciones sucesivas» destacando la necesidad de abordar a las milicias en sus diversos contextos espaciales y temporales. Roger Dupuy (2016), finalmente, destacó la necesidad de estudiar la milicia a escala local; propuso pensarla como una institución marcada por «resurrecciones sucesivas», es decir, por la alternancia entre momentos de movilización y desmovilización. Para el autor, es necesario analizar cuáles fueron en cada contexto los factores que impusieron a los grupos dirigentes relanzar o apaciguar la movilización política a través de la convocatoria miliciana.

Para el caso español, Juan Sisinio Pérez Garzón (1978) analizó las milicias madrileñas entre 1794 y 1874 e identificó la evolución y los cambios en las funciones de esos cuerpos. Su enfoque se caracterizó por un abordaje de historia social donde analiza cómo su composición fue variando a lo largo del tiempo, a la vez que destaca los temores que generaba la movilización miliciana entre las clases dominantes. El autor abordó su transformación posterior y cómo se constituyeron en un actor clave en el enfrentamiento entre liberales y realistas en los años 1820 y 1830.4 De forma coincidente, Víctor Gayol propuso un balance historiográfico respecto a los estudios sobre milicias en España y América Latina, destacando la forma en que estas fueron un instrumento fundamental de las burguesías para construir los estados liberales en el siglo XIX. Gayol sostiene que de 1808 a 1826, la revolución liberal y la definición de los «ciudadanos en armas como garantes de la nación» generaron la «militarización de la política y la sociedad» (2009: 462-464). Manuel Chust y Juan Marchena, por su parte, señalaron que la denominación de miliciano, tanto en la península como en América, debe adjetivarse a efectos de descubrir no solo las continuidades sino también los cambios y rupturas. En el período se habría procesado el tránsito desde cuerpos orientados a la «defensa del Rey y sus posesiones» hacia referentes nuevos como la nación o el ciudadano (2007: 10).

La historiografía sobre las milicias en los años de las revoluciones y las guerras de independencia en Hispanoamérica es vasta. 5 Entre los trabajos más destacados podemos referir el exhaustivo estudio de Clément Thibaud (2003) sobre los ejércitos en el proceso de independencia de Nueva Granada y Venezuela, de Juan Luis Ossa (2014) sobre Chile, de

\footnotetext{
${ }^{4}$ Sobre las milicias de «voluntarios realistas» véase el sugerente trabajo de Paris, Álvaro «Los voluntarios realistas de Madrid. Politización popular y violencia contrarrevolucionaria (1823-1833)» en Rújula, Pedro y Solans, Ramón (eds.), El desafio de la revolución. Reaccionarios, antiliberales y contrarrevolucionarios (Granada, Comares, 2017), 89-106.

${ }^{5}$ Véase Marchena, Juan y Chust, Manuel, Las Armas de la Nación: independencia y ciudadanía en Hispanoamérica (1750-1850). (Madrid, Iberoamericana, Frankfurt am main, 2007), Ortiz Escamilla, Juan (coord.), Fuerzas militares en Iberoamérica, siglos XVIII y XIX. (Ciudad de México, El Colegio de México/El Colegio de Michoacán/Universidad Veracruzana, 2005) o Marchena, Juan y Chust, Manuel (ed.), Por la fuerza de las armas. Ejército e independencias en Iberoamérica, Colección América 12, (Castellón, Universitat Jaume I, Castellón, 2008).
} 
Natalia Sobrevilla (2012) respecto al Perú y de Manuel Chust sobre México (2005). Este último autor propuso un análisis «de la problemática social» que la institución comportó en la construcción del Estado mexicano, en la medida en que la convocatoria apelaba al ciudadano propietario, pero era flexibilizada de acuerdo a las necesidades de los gobiernos locales. Destacó la «intermitencia» como una constante en la historia de las milicias y la explicó a partir de las necesidades de los grupos dirigentes de «abrir» la convocatoria a estos cuerpos o restringirlos según el caso.

En la región platense los abordajes han avanzado, como en otras zonas, desde una historiografía que analizó a las milicias como componente de la organización militar a enfoques más específicos sobre la institución. En este proceso fue importante la renovación en las investigaciones sobre el mundo rural, las clases populares urbanas, los espacios de frontera y la vida política. Un autor fundamental en este tránsito fue Tulio Halperin Donghi (1978 y 2014) y sus estudios sobre la militarización revolucionaria en Buenos Aires y los nexos con la formación de una elite dirigente criolla. Tres aportes del autor son importantes para nuestro enfoque; el crecimiento cuantitativo y cualitativo de las milicias tras las invasiones inglesas, su papel como instrumento político para el encumbramiento de una elite criolla en la capital virreinal, y finalmente, su rol como nexo político e institucional entre la elite y las clases populares.

De la producción historiográfica más reciente debemos destacar la obra de Raúl Fradkin (2009) que propuso pensar a las formaciones milicianas dentro de un conjunto de «tradiciones militares» que se fueron constituyendo desde la colonia. Su objetivo fue analizar estas tradiciones para comprender las posibilidades de intervención política de los sectores subalternos en la etapa revolucionaria y como esta participación influyó en la formación de sus culturas políticas. Para la etapa revolucionaria, Gabriel Di Meglio (2007) analizó a la milicia como espacio de la política plebeya en Buenos Aires a lo largo de un extenso período que va desde 1806 hasta 1829. Asimismo analizó su protagonismo en coyunturas específicas, mostrando el potencial del enfoque micro para el análisis de este tipo de movilizaciones. ${ }^{6}$ Finalmente, debemos destacar la investigación de Alejandro Rabinovich (2013) que abordó los sentidos del proceso de militarización y la conformación de una «sociedad guerrera» durante los años de la revolución.

Otra perspectiva interesante es la que enfoca a las milicias como espacio de formación de ciudadanía. En esa línea, Oreste Cansanello (53) destacó el componente civil y ciudadano

\footnotetext{
${ }^{6}$ Véase también del autor: «Las palabras de Manul. La plebe porteña y la política en los años revolucionarios» en Fradkin, Raúl O. (ed.) ¿Y el pueblo dónde está? Contribuciones para una historia popular de la revolución de independencia en el Río de la Plata (Buenos Aires, Prometeo, 2008): 67-106.
} 
de las prácticas milicianas, un servicio realizado por civiles que no dejaban de serlo por integrar un contingente en armas y que, además, reafirmaban su integración a la sociedad al hacer el servicio. Hilda Sabato (2010: 80), por su parte, destacó como las milicias fueron un espacio de sociabilidad donde se generaban relaciones que implicaban la combinación de elementos previos (rango, jerarquía) con valores surgidos en el contacto con otros (familiaridad, paternalismo).7 Las milicias incidían en la vida política por su carácter de institución armada y jerarquizada, pero sobre todo, por «la forma en que los contemporáneos entendían su papel político», en tanto expresión del derecho y el deber de levantarse en armas frente a la «opresión» (74). Flavia Macías, finalmente, señaló el vínculo entre la dimensión política de la ciudadanía, representada por la opinión pública y la participación electoral, y su componente militar asociado al servicio miliciano (2010: 2-3). La «invención del ciudadano», a juicio de Macías, se produjo a partir de la participación de los vecinos en la vida política, tanto en su rol de electores como de milicianos (6).

La historiografía uruguaya sobre el siglo XIX ha transitado escasamente la temática. El acercamiento a las formas de socialización política sigue siendo tributario de una producción de cuño tradicionalista que ubicó a los partidos como sujetos centrales y constituyentes de la vida política. Elecciones, opinión pública, prensa, asociacionismo, contingentes en armas, han sido pensados y ordenados en un relato que ha girado en torno a la lucha de partidos, a la que se ha otorgado un carácter permanente que se confunde con los orígenes mismo del Estado. ${ }^{8}$ Para el período colonial no existen trabajos que aborden de forma específica a las milicias en Montevideo o la banda oriental del río Uruguay. Los primeros antecedentes significativos aparecen en estudios que abordaron de forma panorámica o específica las invasiones inglesas. 9 Las milicias formadas en la campaña oriental y su integración en el ejército revolucionario en 1811 fueron estudiadas en los años sesenta por Agustín Beraza (1967) y recientemente, desde una perspectiva centrada en los procesos de reclutamiento y deserción, por Daniel Fessler (2015). Sobre las milicias montevideanas en el convulsionado período que va desde 1810 a 1830, los antecedentes son

\footnotetext{
${ }^{7}$ Véase también: Sabato, Hilda, «Los desafíos de la República. Notas sobre la política en la Argentina pos Caseros» en Estudios Sociales 46 (2014): 77-117.

${ }^{8}$ Véase especialmente Pivel Devoto, Juan E., Historia de los Partidos Políticos en el Uruguay, Tomo I, (Montevideo, Claudio García y Cía, 1942) e Historia de los partidos y de las ideas políticas en el Uruguay:la definición de los bandos (1829-1838). (Montevideo, Ediciones del Río de la Plata, 1956). Un agudo análisis sobre los planteos del autor en Rilla, José, La actualidad del pasado. Usos de la historia en la política de partidos del Uruguay (1942-1972). (Montevideo, Debate, 2008).

${ }^{9}$ Entre los estudios panorámicos véase: Bauzá, Francisco, Historia de la Dominación Española en el Uruguay, T. I. (Montevideo, Palacio del Libro, 1929) y Blanco Acevedo, Pablo, El Gobierno Colonial en el Uruguay y los orígenes de la Nacionalidad, Tomo II, Biblioteca Artigas, Colección de Clásicos Uruguayos, Volumen 150. (Montevideo, Barreiro y Ramos, 1975). De los específicos véase Luzuriaga, Juan C., La reconquista de Buenos Aires. El cenit de Montevideo colonial. (Montevideo, Planeta, 2017).
} 
escasos y recientes, aunque se apoyan en una importante renovación de los estudios sobre este período. ${ }^{10}$ Finalmente, las guardias nacionales creadas en las primeras décadas del Estado Oriental y de importante incidencia política, tampoco han sido abordadas de forma específica. Para este último marco temporal, resulta importante mencionar las investigaciones de Mario Etchechury (2012 y 2015), que avanzaron sobre la formación de milicias integradas por residentes vascos, catalanes y canarios en Montevideo durante la Guerra Grande y su incidencia en la generación de acciones colectivas.

\section{Las milicias en Montevideo}

La institución miliciana, como se ha visto, tuvo su origen en el continente europeo y se trasladó a América con el objetivo de complementar los siempre escasos ejércitos de línea metropolitanos. El fundamento teórico para su convocatoria estaba en las leyes históricas de la monarquía que establecían la obligación del vecino de servir en defensa del rey y sus posesiones cuando la necesidad lo imponía. ${ }^{11}$ Juan Marchena (1992: 104-105), en un esfuerzo por ordenar este universo de formaciones, ha distinguido entre las milicias urbanas (constituidas en las ciudades, organizadas especialmente a partir de los gremios y dirigidas por los cabildos u otros vecinos distinguidos) y las milicias rurales (conformadas en zonas de frontera, dirigidas por capitanes de guerra e integradas por hacendados y peones). Durante los siglos XVI y XVII el régimen de milicias evolucionó de forma provisional, los cuerpos se formaban en situaciones de emergencia y luego se desmovilizaban cuando pasaba el peligro (Kuethe 103-104). Las autoridades metropolitanas y los funcionarios residentes en América debieron asumir la tensión que generaban dos imperativos contrapuestos. Por un lado, la necesidad de apelar a la movilización general para la defensa del territorio y por otro, el temor al incremento del poder de los grupos locales.

Esta primera organización comenzó a modificarse a mediados del siglo XVIII, cuando la monarquía emprendió una importante reestructura militar orientada a asegurar el control

\footnotetext{
${ }^{10}$ Algunos trabajos claves de la renovación en los estudios de la historiografía uruguaya sobre el período son Barrán, José Pedro «La independencia y el miedo a la revolución social», en Revista de la Biblioteca Nacional 24, (1986): 65-77; Frega, Ana, Pueblos y soberanía en la revolución artiguista. La región de Santo Domingo Soriano desde fines de la colonia a la ocupación portuguesa, (Montevideo, Ediciones de la Banda Oriental, 2007). Específicamente sobre milicias véase «Revolución y contra-revolución en Montevideo en 1810: el frustrado motín de la guarnición militar» en Frega, Ana (Coord.), La vida política en Montevideo: elites y sectores populares en tiempos de revolución, (Montevideo, CSIC, Universidad de la República, 2018), 17-42; Ferreira, Pablo, «Los amotinados de la Matriz. Una aproximación al estudio del conflicto social y político en el ocaso del Poder Español en Montevideo» en Avances de Investigación, Tomo Docentes, (Montevideo, FHCE, 2013): 2342; «Ciudadanos en armas. La experiencia de la milicia cívica en Montevideo, 1815-1817» en Claves. Revista de Historia, N. ${ }^{\circ} 2$ (2016): 9-45 y “"Que se vaya la Patria al ajo...” El año XV, las milicias cívicas y los espacios de resistencia al poder artiguista en Montevideo.» en Revista Historia para todos, N. ${ }^{\circ} 5$ (2017), 10-23 y «La rendición de la Montevideo...».

${ }^{11}$ La idea de «leyes antiguas de la Monarquía» la entendemos en el sentido asignado por José Carlos Chiaramonte de una referencia a un conjunto de «leyes fundamentales que rigen la vida de la sociedad». Véase Chiaramonte, José Carlos, «Acerca del origen del Estado en el Río de la Plata», en Anuario IEHS 10 (1995), 30.
} 
de sus posesiones coloniales. Luego de la toma de La Habana por los ingleses en 1762 estas reformas se aceleraron. La corona española aumentó el gasto militar en fortificaciones, envió fuerzas veteranas (regimientos fijos) para defender las colonias y procuró la multiplicación y el disciplinamiento de las milicias (Alemano 181). El reglamento de milicias elaborado para Cuba en 1769 y los que se impulsaron para las demás posesiones coloniales en los años siguientes constituyeron, por primera vez en América, un sistema dotado de un modelo organizativo a escala imperial (Morelli 417). Además de universalizar el alistamiento, los esfuerzos de las autoridades se orientaron a transformar parte de las milicias en «disciplinadas» o «regladas», lo que implicó dotarlas de reglamento, incorporar oficiales veteranos para su instrucción, incluir a las elites locales en los cuadros de oficiales e incorporar a los sectores populares a integrar los regimientos. Según Allan Kuethe (110), la reforma instituía un pacto político, económico y militar con los notables criollos, los que a cambio de la financiación de los cuerpos recibieron ventajas comerciales y un incremento de su poder político.

En el Río de la Plata, una Real Instrucción en 1764 avanzó en el ordenamiento de las milicias, ${ }^{12}$ pero fue recién con el Reglamento para las Milicias disciplinadas de Infantería Caballería del Virreinato de Buenos Aires, aprobado en enero de 1801, que estas gozaron de un marco organizativo y normativo. El reglamento pretendía disciplinar catorce mil hombres en el conjunto del virreinato, establecía las plazas veteranas y la oficialidad voluntarias para cada tipo de regimiento, los límites de edad, la duración del servicio, las prioridades para el alistamiento y las excepciones. Establecía además las actividades de instrucción, otorgaba el fuero militar y establecía un prest igual al de las tropas veteranas pero solo para cuando fueran llamadas a las armas. ${ }^{13} \mathrm{El}$ reglamento dividía los contingentes sobre la base de identidades colectivas (que iban desde factores ocupacionales, referencias a la «patria» de origen o factores étnicos) y establecía que los cuerpos formados por «blancos» deberían integrarse por individuos que «se conocen por españoles». ${ }^{4}$

En Montevideo, la existencia de formas de servicio militar por parte de los vecinos se remonta a la fundación de la ciudad y a las necesidades de organizar la defensa ante los grupos amerindios y el avance lusitano en una zona de frontera imperial. La ocupación del

\footnotetext{
${ }^{12}$ Respecto al impacto de estas reformas véase Birolo, 2014.

13 "Reglamento para las Milicias disciplinadas de Infantería y Caballería del Virreynato de Buenos Ayres, aprobado por S. M. y mandado observar inviolablemente" Aprobado por Real Cédula del 14 de enero de 1801. Disponible en https://es.wikisource.org/wiki/Reglamento_para_las_Milicias_disciplinadas_de_Infanter\%C3\%Ada_y_Caballer\%C3\%Ada_del_Virreynato_de_Buenos-Ayres. Un análisis de sus contenidos en Beverina, Juan, El Virreinato de las Provincias del Río de la Plata. Su organización militar. (Buenos Aires, Círculo Militar, 1935). 310-316.

${ }^{14}$ «Reglamento...», art. 24 .
} 
espacio se gestó a partir de una red de ciudades que conectaban a partir de un territorio cuya ocupación era discontinua y estaba en disputa entre las elites hispanocriollas, las parcialidades amerindias y los avances lusitanos. El Reglamento de 1801 dispuso que los cuerpos de milicias se organizarían de la misma forma y con el mismo número que en la capital virreinal. ${ }^{15}$ Estos adquirieron gran protagonismo político a partir de las invasiones inglesas al Río de la Plata entre 1806 y 1807. Uno de los aspectos destacados por la historiografía es el ingreso de las clases populares a la milicia, así como el hecho de que los contingentes convocados para atender necesidades bélicas coyunturales no fueron desmovilizados (Halperin, 2014: 187, Di Meglio 2007: 86-87). El proceso de formación y transformación de las milicias resultó a partir de entonces dinámico; mientras algunos cuerpos se disciplinaban y pasaban a estar en armas de forma permanente, nuevos sectores de la población eran convocados para un tipo de movilización intermitente, sirviendo en algún momento del año y reincorporándose a sus tareas y residencias normales. Convivieron milicias altamente disciplinadas - como los voluntarios del Río de la Plata o el Regimiento de Infantería Ligera organizados en 1807-, con formaciones que tuvieron un régimen más laxo, tal el caso de cuerpos constituidos por grupos «nacionales» - milicias de catalanes o integradas por «emigrados» de Buenos Aires- o contingentes formados por sujetos corporativos, como ser el comercio de la ciudad. ${ }^{16}$

Este proceso acelerado de constitución de grupos milicianos influyó en la vida política de la ciudad. Para las autoridades resultó difícil encauzar a sectores de la población que ahora estaban en armas y que habían vivido un inédito proceso de politización a partir de la crisis de la monarquía española y sus impactos en el Río de la Plata. Este proceso se hizo en clave conservadora del orden vigente, en la medida en que la movilización apelaba a la defensa de la monarquía y su soberanía sobre los territorios americanos. El llamado a la

\footnotetext{
${ }^{15}$ Cabe aclarar que los números de integrantes de las compañías y la cantidad de estas que conformaban los batallones no eran aleatorios, sino que replicaban las disposiciones militares de los ejércitos de línea en especial las «Ordenanzas de Su Majestad para el régimen, disciplina, subordinación y servicio de sus exércitos», dictadas por Carlos III en 1768.

${ }^{16}$ Las milicias de catalanes (llamadas de forma indistinta «miñones» 0 «miqueletes») se habían constituido en 1806, en vísperas de la organización de la reconquista de Buenos Aires. Integraron a comerciantes y manufactureros catalanes, con sectores medios (tal el caso de algunos pulperos) y también a grupos plebeyos que formaban parte del universo de trabajadores vinculados a las «empresas» catalanas. El Regimiento de Infantería Ligera y los Voluntarios del Río de la Plata, por su parte, fueron formados por una Junta de Guerra reunida en Buenos Aires el 23 de julio de 1807, unificando varios contingentes creados durante las invasiones inglesas. Por su parte, el Tercio de Emigrados de Buenos Aires se formó a fines de 1810 organizado por el comerciante bonaerense José Neyra, que había salido de esa ciudad enfrentado a la junta revolucionaria. Finalmente, en marzo de 1811, a efectos de fortalecer la defensa de la ciudad ante el inminente avance de las fuerzas patriotas, se constituyó el Batallón de Distinguidos del Comercio, organizado por la junta de comerciantes de la ciudad.
} 
milicia otorgaba un poder inédito a sectores de la sociedad que habían tenido un rol subalterno y generaba temores en los reductos más cercanos al poder gubernamental. ${ }^{17}$

Las milicias urbanas tuvieron una activa participación en las tumultuosas jornadas de setiembre de 1808 que terminaron en la formación de una Junta de Gobierno en la ciudad y fueron protagonistas de las disputas políticas de 1810. En los años siguientes, cuando Montevideo se transformó en el baluarte españolista de la región, las milicias incrementaron su protagonismo político. En 1811 la ciudad fue sitiada durante cinco meses, sin recibir refuerzos de tropas veteranas, lo que aumentó la importancia defensiva de las milicias. En julio de 1812, ante las perspectivas de un nuevo sitio, el capitán general Gaspar de Vigodet decretó la movilización de todos los vecinos y habitantes, a los que dio ocho días para integrarse a alguno de los cuerpos existentes. La convocatoria es interesante en la medida en que no se hizo para el servicio al rey, sino que se encontraba atravesada por referencias republicanas que convocaban a los «ciudadanos» a defender «los derechos de la nación» (CNAA, 1966: 41-43). En 1812 la constitución gaditana había determinado la creación de la «milicia nacional» como una fuerza integrada por ciudadanos y regida por los ayuntamientos y si bien su jura en Montevideo fue posterior al decreto aludido, la influencia de las nuevas referencias políticas en la península puede apreciarse en el documento.

En los meses finales de dominio español sobre la ciudad, las milicias urbanas fueron ganadas por los sectores más intransigente y reacio a toda posibilidad de armisticio o rendición pactada, siendo uno de los espacios políticos en que se dirimió la lucha facciosa entre los grupos notables locales (Ferreira y Frega, 2016). Tras la rendición de la ciudad en junio de 1814, las milicias urbanas se disolvieron y muchos de sus jefes fueron traslados como prisioneros a Buenos Aires.

\section{Las milicias cívicas}

Las milicias cívicas surgieron en el marco de la revolución y las guerras de independencia como un híbrido entre tradiciones coloniales e innovaciones surgidas en esta etapa. Las milicias creadas luego de 1808 en la península, tanto en la zona ocupada por los franceses como en la resistente, fueron rompiendo «el esquema estamental con el cual se conformaron los cuerpos de vecinos del Antiguo Régimen» (Gayol 466-468). La dinámica de revolución y guerra en la península hizo surgir la milicia nacional de 1812, que fue el antecedente de la milicia cívica. Según Manuel Chust y José Serrano (2007:3-4), el adjetivo «cívicos» remitía

\footnotetext{
${ }^{17}$ Vale aquí el planteo del historiador español Pedro Rújula (2011) quien propuso la idea de una «densificación» del universo político de las clases populares en la etapa de la guerra de independencia. Consideramos que tal proceso también se dio en Hispanoamérica y que tuvo a la milicia como uno de sus lugares más destacados.
} 
a «ciudadanos», un concepto que luego de la revolución francesa invocaba la «asunción de derechos políticos y civiles individuales», uno de los cuales era la defensa armada de la nación.

Entre agosto y setiembre de 1814, con la ciudad de Montevideo bajo la soberanía del Directorio de las Provincias Unidas, se conformó el primer cuerpo que tomó la denominación de milicia cívica y tuvo por base los tercios formados en Buenos Aires en setiembre de $1812 .{ }^{18} \mathrm{El}$ fundamento expresado por las autoridades para crear este cuerpo era la necesidad de otorgar a los «patriotas» la posibilidad de «ejercitar su declarada adhesión al servicio del Estado» (CNAA 1978: 43). El nuevo contingente tuvo una existencia efímera, desmovilizándose poco antes del ingreso de las tropas orientales a la ciudad. La experiencia de estos meses, sin embargo, fue fundamental para la reorganización posterior de la milicia sobre una base nueva y vinculada a la revolución.

La etapa de gobierno artiguista en Montevideo que se inicia en marzo de 1815 evidenció la complejidad que habían asumido las formaciones militares y milicianas en la Provincia Oriental. ${ }^{19}$ El ejército que ingresó a la ciudad, comandado por Fernando Otorgués, tenía su origen en diversos contingentes que iban desde los Blandengues de Frontera hasta individuos que habían integrado milicias coloniales en la campaña o en Montevideo. En el transcurso de la revolución estas fuerzas irregulares se habían ido constituyendo en contingentes organizados al mando de los jefes orientales. Estas tropas, verdadero híbrido organizativo y de tradiciones militares, fueron vistas por una parte de las elites montevideanas como un ejército de ocupación y eran, de forma sistemática, acusadas de contribuir al desorden y la «anarquía» por sus actos de indisciplina. ${ }^{20}$

El 15 de mayo de 1815, en el marco de una importante crisis política en la ciudad y ante los rumores que alertaban sobre el inminente arribo de una expedición española de reconquista, el Cabildo solicitó autorización a Fernando Otorgués para la reorganización del cuerpo cívico (Ferreira 2016a: 23-24). El objetivo, según expresaba un bando distribuido el 3 de julio, era constituir un contingente armado que ayudara a imponer el orden y «hacer

\footnotetext{
${ }^{18}$ Sobre los tercios formados en Buenos Aires véase Di Meglio 2007: 136-143.

${ }^{19}$ Sobre el gobierno artiguista en la Provincia Oriental y de modo más específico en la ciudad de Montevideo véase Sala, Lucía, Rodríguez, Julio y de la Torre, Nelson, Artigas y su revolución agraria 1811-1820, (Ciudad de México, Siglo Veitiuno Editores, 1987); Frega, Ana «La virtud y el poder. La soberanía particular de los pueblos en el proyecto artiguista», en Goldman, Noemí y Salvatore, Ricardo. Caudillismos rioplatenses. Nuevas miradas a un viejo problema. (Buenos Aires, Eudeba, 1998), 101-133 y «El Reglamento de Tierras de 1815: justicia revolucionaria y virtud republicana» en Caetano, Gerardo y Ribeiro, Ana (Coord.), Tierras, Reglamento y revolución. Reflexiones a doscientos años del Reglamento Artiguista de 1815, (Montevideo, Planeta, 2015): 487-532.

${ }^{20}$ El principal contingente, los «Dragones de la Patria» o «de la Libertad», comandados por Fernando Otorgués, tenían al igual que buena parte del ejército artiguista un origen miliciano, pero se habían convertido en ejércitos veteranos durante la revolución.
} 
efectiva la seguridad individual» (CNAA 1994:34). La elite capitular — revolucionaria en su posición antiespañolista pero conservadora ante el radicalismo e igualitarismo artiguistabuscaba generar a partir de la milicia un contrapeso al poder de las tropas orientales.

La milicia cívica estuvo en armas durante todo el período de gobierno oriental en Montevideo. En enero de 1816 se produjo una reorganización miliciana para el conjunto de la provincia que no afectó la organización de la infantería cívica de la ciudad, pero sí la caballería extramuros. Asimismo, en esta fecha se instó a los no alistados en la infantería a incorporarse a la artillería (CNAA 1991: 129). Las tensiones más graves al interior de los cuerpos, como veremos más adelante, se generaron en la segunda mitad de 1816, cuando la invasión lusitana sumió a la Provincia Oriental nuevamente en guerra.

Tras el ingreso de las tropas lusitanas a Montevideo, en enero de 1817, una de las primeras acciones de las autoridades fue reorganizar las milicias y buscar su adhesión al nuevo orden. Los informes recibidos mientras se planificaba la invasión conducían a las autoridades lusitanas a considerar que el «arreglo de la milicia» era un problema complejo a resolver; un asunto que podía contribuir a la generación de consensos entre las elites o podía traer dificultades. Entre las «instrucciones» recibidas por el general Carlos Federico Lecor para su expedición a la provincia estaba la conservación de los cuerpos de milicias existentes, aunque «sin esmerarse mucho en su disciplina, a fin de no mortificar los hombres y conservando sus privilegios» (CNAA 1998a: 276). En este punto se sintetizaba buena parte del problema político asociado a la milicia: la participación era un derecho y un deber, por tanto, implicaba privilegios y al mismo tiempo obligaciones de servicio. No se debían quitar los primeros y era deseable no recargar a los ciudadanos con los segundos. Siguiendo tal premisa, los lusitanos no hicieron llamados al alistamiento general durante el período que gobernaron la ciudad y mantuvieron a la milicia en una situación de latencia, es decir, formada, con sus mandos designados y haciendo esporádicos ejercicios disciplinares. La importante presencia de tropas veteranas no hizo a la milicia necesaria para funciones defensivas y es posible que se tuvieran temores sobre su fidelidad al nuevo orden.

\section{Un ciclo tumultuario y motinero}

En este apartado nos proponemos una mirada de conjunto respecto al ciclo de tumultos y motines milicianos que se inició con las invasiones inglesas y que tuvo su punto culminante con la revolución de las milicias cívicas en los primeros días de setiembre de 1816. ${ }^{21}$ La frecuencia de este tipo de episodios y su repetición en instancias críticas para la

\footnotetext{
${ }^{21}$ La idea de un «ciclo tumultuario» la tomamos del trabajo de Fradkin, Raúl, «Cultura política y acción colectiva en Buenos Aires (1806 -1829): un ejercicio de exploración» en Fradkin, Raúl, (Ed.) ¿Y el pueblo dónde
} 
vida de la ciudad permiten sostener que estos formaron parte del repertorio de acciones contestatarias con que contaron diversos sujetos individuales y colectivos para expresar su descontento o abrir espacios de negociación ante decisiones de las autoridades. En algunos casos, llegaron a tener el objetivo de cambiar las alianzas y la correlación de fuerzas en la ciudad.

Tras el arribo de noticias sobre la ocupación inglesa de Buenos Aires en julio de 1806 se produjo una intensa y rápida militarización de la población montevideana a efectos de organizar la reconquista. Expulsados los ingleses de la capital virreinal la inestabilidad política en la región no se disipó y no fue fácil proceder al desarme de las milicias. El 20 de octubre de ese año, por ejemplo, se generó «un movimiento de conmoción» en el muelle de la ciudad que tuvo por protagonistas a las milicias integradas por catalanes. Según consignan las actas capitulares, integrantes de la Armada que venían de enfrentarse con una cañonera inglesa fueron apedreados por una «multitud» que los acusaba de no haberla hundido o traído al puerto. Entre quienes atacaron a los marinos se encontraban integrantes del cuerpo de miñones. En el acta los capitulares expresaban su preocupación ante la decisión del gobernador de exigirles el depósito de sus armas. Se señalaba el «disgusto» que esto generaba en las «voces generales» de la ciudad y el temor ante una posible reacción. Se establecía, ademas, que en caso de tener que repeler al enemigo, los miñones podrían negarse a tomar las armas o hacerlo sin el ímpetu anterior (RAGA 1917: 327-328). La preocupación radicaba en dos aspectos en principio irreconciliables: la necesidad defensiva de estos contingentes y el temor a sus acciones disruptivas del orden.

En setiembre de 1808, con el telón de fondo de la crisis de la monarquía española y el avance de Napoleón en España, el virrey del Río de la Plata Santiago Liniers decidió remover al gobernador de Montevideo Francisco Javier de Elío de su cargo y designar a Juan Angel de Michelena en su lugar. ${ }^{22}$ La noche del 20 de setiembre hubo una intensa movilización en la ciudad que desencadenó, a la mañana siguiente, la creación de una Junta de Gobierno que respaldó la permanencia de Elío en su cargo. Entre las acciones ocurridas la noche anterior se puede apuntar el trasiego de grupos armados por distintos puntos de la ciudad haciendo «bulla»y «gritando» en defensa del gobernador, la concentración de una «multitud» con antorchas entorno al Fuerte (residencia del gobernador y una de las principales construcciones militares de la ciudad) y los tumultos ocurridos frente a la residencia del

está? Contribuciones para una historia popular de la revolución de independencia en el Río de la Plata, (Buenos Aires, Prometeo, 2008): 28-30.

${ }^{22}$ Sobre el episodio véase Frega, Ana, «La Junta de Montevideo de 1808», en Chust, Manuel (coord.). 1808. La eclosión Juntera en el Mundo Hispánico. (Ciudad de México, El Colegio de México, Fondo de Cultura Económica, 2007) 242-268 y Ferreira «La guerra de independencia...». 
administrador de aduanas José Prego de Oliver. Según declaraciones del capitán de la Real Armada José Obregón, en el expediente que levantó la Real Audiencia sobre los hechos ocurridos en Montevideo, el conjunto de «sediciosos» que se manifestó por las calles estaba integrado, principalmente, por oficiales y milicianos de los regimientos de Infantería Ligera y de Voluntarios del Río de la Plata que se hacían notar por la presencia de sus músicos (Pivel 1962: 534). El alférez de navío Francisco de Nava, por su parte, indicó que al llegar a su casa «le sorprendió la gritería que oyó » y tras subir a la azotea «notó que quien[es] causaba[n] el alboroto eran algunas gentes de color y varios oficiales de los Cuerpos de Balvín y Murriondo [sic] con la música del primero que empezaron a discurrir por las Calles gritando que en el dia siguiente se haría Cavildo abierto» (Pivel 1962: 539). Juan Francisco Bermúdez, oficial del regimiento de Voluntarios del Río de la Plata, declaró que sobre la medianoche «una porción de Oficiales de los Cuerpos de Murriondo y Balvín [sic] con algunos Comerciantes con hachas encendidas y la música tocando paso de ataque» recorrieron las calles gritando «muera Michelena, muera el traidor, muera Buenos Aires y viva nuestro Gobernador». Estos se habrían dirigido hasta el Fuerte «con esa gritería» y en el momento en que salió el gobernador «lo pasearon diciéndole que primero derramarían la última gota de sangre antes que permitir sacar de Montevideo a su Gobernador» (Pivel 1962; 573).

La mayor parte de la oficialidad de estos cuerpos juró fidelidad a la Junta montevideana. Las diversas milicias se convertían de esta forma en actores y en lugares en que se desarrollaba la movilización política en la ciudad. En ellas se procesaban las diversas tensiones y conflictos que dividían a la sociedad colonial. Los regimientos creados tras la salida de los ingleses en 1807, principales protagonistas de los hechos, incorporaban a una parte importante de los vecinos varones y también a sectores plebeyos; eran espacio habitual de tertulias, de circulación de información y de generación de liderazgos.

El protagonismo de la milicia en 1808 -aun teniendo en cuenta los márgenes que abría una convocatoria política amplia- se fundamentó en la defensa de los derechos de la monarquía, en la oposición al virrey acusado de actuar al servicio de Bonaparte y en el apoyo a la continuidad del gobernador de la ciudad. Dos años después varias de estas coordenadas cambiaron. En mayo de 1810 llegaron noticias de la disolución de la Junta Central y Gubernativa del Reino ante los avances franceses y la constitución de un Consejo de Regencia, de discutida legitimidad, en la ciudad de Cádiz. Paralelamente, en Buenos Aires, un cabildo abierto decidía desconocer a la Regencia y sustituir al virrey por una Junta de gobierno que tutelara los derechos de Fernando VII. Esta junta buscó la adhesión del conjunto del virreinato, empezando por las ciudades más cercanas. 
En Montevideo los hechos produjeron una fuerte división entre las notabilidades locales, enfrentando a los partidarios del reconocimiento a la Junta con quienes se mostraron afines a mantener su lealtad a la Regencia. Entre mayo y junio estos últimos lograron imponer sus posiciones en distintas instancias de decisión, en las que tuvieron un gran protagonismo los mandos de la Armada, en especial el comandante del Apostadero Naval José María Salazar. La tensión política, sin embargo, fue en aumento durante esos meses, circulando constantes acusaciones que ponían en duda la fidelidad de los distintos grupos en pugna (Frega 2018; Ferreira 2016b).

El 12 de julio se produjo un motín, finalmente controlado por las fuerzas leales a la regencia, en la guarnición militar de Montevideo. Este tuvo como protagonistas a los regimientos de Infantería Ligera y de Voluntarios del Río de la Plata, los dos cuerpos formados luego de las invasiones inglesas y sobre los que hemos referido antes. ${ }^{23}$ Los hechos se produjeron en la madrugada y los regimientos se atrincheraron, uno en el Cuartel de Dragones ubicado en el extremo sur de la ciudad y el otro en la Ciudadela, construcción militar que franqueaba el ingreso a la plaza y era su punto ubicado más al oriente. ${ }^{24} \mathrm{En}$ ambos lugares había cañones y armas a disposición de los amotinados lo que hizo temer un enfrentamiento de dimensiones considerables. Entre las dos y las cuatro de la madrugada los amotinados hicieron llegar un primer petitorio a las autoridades, al tiempo que detenían y apresaban a los soldados que integraban la partida del sargento mayor Diego Ponce de León (MD 1965b: 292). Mientras una buena parte de los habitantes de la ciudad dormía, las amenazas y negociaciones se sucedían entre las autoridades y los jefes amotinados.

La movilización de diversos contingentes para contener a los amotinados generó, según consigna un «diario anónimo» que narró los hechos, que la «conmoción» y el «alboroto» se desplegara por buena parte de la ciudad (MD 1965a: 218-219). La marina estaba acuartelada en el «barracón» y había tomado posiciones en el contiguo convento de San Francisco, al tiempo que las milicias urbanas (no plegadas al motín) estaban reunidas en las «casernas de las murallas» (Larrañaga y Guerra 102). En la mañana, los mandos de los regimientos amotinados dieron a conocer una proclama donde exigían el reembarco de

\footnotetext{
${ }^{23}$ Sobre el motín de la guarnición militar de 1810 véase Bauzá, Historia de la Dominación Española... t. III, 13; Pivel Devoto, Juan E, Raíces coloniales de la revolución oriental de 1811 (Montevideo, Monteverde, 1952): 225-233; Reyes Abadie, Washington, Bruschera, Oscar y Melogno, Tabaré, El ciclo artiguista, Tomo I, Montevideo, Ediciones de la Banda Oriental, 1968), 34-36; Bentancur, Arturo, El puerto colonial de Montevideo, tomo 2. (Montevideo, FHCE, Universidad de la República, 1999) 73 y ss; Aguerre Core, Fernando, Los últimos españoles. Autonomía y lealtad a la Corona en el Montevideo insurgente (1802-1815), (Montevideo, Linardi y Risso, 2011).99-100; Ribeiro, Ana, Los muy fieles. Leales a la Corona en el proceso revolucionario rioplatense. Montevideo/Asunción, 181o-1820, t. 2, (Montevideo, Planeta, 2013) 95, y especialmente Frega, «Revolución y contra-revolución....»y Ferreira «La guerra de independencia...», 49-50.

${ }^{24}$ Véase mapa anexo.
} 
la marina y la separación de su cargo del sargento mayor Diego Ponce de León, uno de los líderes del bando regentista. Referían a los «infinitos desaires» sufridos por sus regimientos en los últimos meses, señalando que la convocatoria de las autoridades a las milicias urbanas y el desembarco de la marina habían «colmado» la paciencia de las tropas a su mando (MD 1965b: 165).

En las horas siguientes, sin embargo, las fuerzas de la Marina, los cuerpos de milicias no plegados al motín y un número muy importante de personas, se concentraron en la plaza principal de la ciudad y avanzaron hasta rodear a los amotinados en el cuartel de Dragones. Lograda la rendición del regimiento de Infantería Ligera se avanzó sobre la Ciudadela, estableciéndose una negociación entre los integrantes del Cabildo y los jefes del motín, que finalmente decidieron deponer su actitud. Si bien se dijo que no habría represalias, en los días siguientes Prudencio Murguiondo, Luis Vallejo, Patricio Beldón y José Cano, considerados junto a Juan Balvín Vallejo, los principales líderes del motín, fueron enviados como prisioneros a la península.

El episodio fue central para la definición política de Montevideo en la coyuntura de 1810. Si bien los líderes del motín no incluyeron entre sus reivindicaciones el reconocimiento a la junta bonaerense, su acción fue interpretada como orientada a tal fin. ${ }^{25}$ En ese sentido, ha sido leído por parte de la historiografía como el último intento de los partidarios de la unidad con la capital, el llamado «partido americano» al que refieren múltiples documentos, por incidir sobre las decisiones de las autoridades. Desde esta perspectiva, los amotinados habrían sido el brazo armado de una trama conspirativa surgida entre las notabilidades, que tenía nexos con las nuevas autoridades de la capital virreinal y que al obtener el apoyo de los mandos logró la adhesión de la tropa.

Esta lectura es válida analíticamente como explicación del comportamiento de las jerarquías pero tiene limitaciones para analizar el accionar de los subordinados. La hipótesis del complot es necesario enriquecerla con elementos que remitan a las propias milicias como espacio de acción política y a sus nexos con otros actores sociales y grupos en armas. La adhesión de los mandos medios y de la tropa miliciana debió requerir la apelación a diversos factores y, en ese aspecto, la incertidumbre, el temor al desarme de los cuerpos o la idea de vulneración de derechos pueden haber sido factores trascendentes para que fuera aceptable por amplios sectores la idea del motín.

\footnotetext{
${ }^{25}$ En diversas cartas enviadas las semanas previas al motín queda explícita la adhesión de los mandos a la Junta bonaerense. Véase «Prudencio Murguiondo a la Junta de Mayo, Montevideo, 6 de junio de 1810» y «Juan Balvín Vallejo a la Junta de Mayo, Montevideo, 6 de junio de 1810» en García Flavio (sel.) «El proceso de gestación de la revolución de los pueblos orientales a través de una selección documental de 1810», en Boletín Histórico del Ejército, 84-87, (1960), 78-79.
} 
Otro episodio a ser incluido en este ciclo de acciones contestatarias fue el motín, descripto al inicio de este artículo, ocurrido la noche del 20 de junio de 1814, luego de que se acordara la capitulación de la ciudad de Montevideo ante las fuerzas del Directorio de las Provincias Unidas del Río de la Plata. La capitulación ponía fin a un largo asedio que, desde mayo de 1814, incluía el bloqueo naval de la ciudad. Desde ese momento se había hecho muy difícil de sostener la situación para las autoridades: faltaban alimentos, los sitiadores contaminaban los pozos de agua, se expandían enfermedades y se extendía un clima de agitación y tensión social que, según las fuentes, resultaba explosivo (Ferreira 2018: 64-67).

En ese contexto se produjo el motín de las milicias urbanas en la iglesia Matriz, punto donde estaban acuarteladas desde los primeros días del mes. Los sublevados, dirigidos por un comerciante emigrado de Buenos Aires llamado José Neyra, se rebelaron contra el comandante Domingo Loaces, quien fue «denodado» e «insultado» por los milicianos (Acuña de Figueroa 345-346). Este último logró escapar, llegó al cuartel de la Ciudadela y consiguió retornar con el apoyo de tropas veteranas a las que ubicó frente a la Iglesia en posición de entrar en combate. En las horas siguientes se produjo una negociación que culminó en la disolución del motín evitando así un derramamiento de sangre.

El historiador Francisco Bauzá (197) señala que durante el motín «se oyeron allí, y en otras partes de la ciudad, voces de imueran los traidores!». No tenemos constancia de que los amotinados llegaran a plantear reivindicaciones, más allá del rechazo a la rendición de la ciudad y la acusación de cobardía a las autoridades. José Neyra, como hemos visto, había emigrado de Buenos Aires en 1810 donde había tenido una actuación destacada en oposición al nuevo régimen. Sus perspectivas en un escenario de rendición de la ciudad aparecían muy comprometidas.

A primera vista, resulta difícil imaginar un triunfo de los amotinados sobre las tropas veteranas que pudiera torcer la decisión de rendir la ciudad. La llegada de contingentes peninsulares luego de 1813 había dotado a la ciudad de tropas veteranas que superaban ampliamente a las milicias. Los protagonistas parecen haber actuado siguiendo impulsos diversos entre los que podríamos anotar el rechazo a las decisiones de los mandos militares, las rivalidades con las tropas veteranas o las dificultades que generaba la falta de pago y la reducción de las raciones. Lo que parece claro es que el motín estuvo ligado a un conjunto de acciones colectivas producidas los meses previos y aparece, al igual que en 1810, como parte de un repertorio de prácticas utilizado de modo pragmático para contestar las decisiones de quienes gobernaban. 
Los casi dos años de gobierno oriental en Montevideo, entre 1815 y 1817, fueron ricos en episodios de movilización social. Uno de los más importantes se produjo en el mes de mayo de 1815 y tuvo por epicentro el cuerpo capitular, generando una profunda crisis política, en la medida en que una parte importante de las notabilidades locales desafió las órdenes artiguistas y procuró ganar para su partido al principal jefe militar y político de la ciudad, Fernando Otorgués (Frega, 1998).

Un nuevo episodio de características tumultuarias se produjo en julio de 1815 y tuvo como protagonistas a las recién formadas milicias cívicas. Las fuerzas orientales habían ingresado a la ciudad en febrero y habían autorizado la reorganización de los cuerpos milicianos en mayo. El proceso de alistamiento y elección de sus oficiales se había hecho durante junio, comenzando luego la realización de ejercicios disciplinares.

Según consta en las declaraciones del sargento mayor del batallón de infantería cívica, Manuel Campus Silba, en un sumario hecho a diversos milicianos por actos de indisciplina, resultó problemática la organización inicial de las compañías. ${ }^{26} \mathrm{El} 19$ de julio, mientras se pasaba revista al batallón de infantería, se le hizo una advertencia al miliciano Francisco Cordones — «con bastante moderación» según el sargento mayor- por encontrarse «formando Corrillos y conversando a gritos, pitando [fumando], y haciendo quanta clase de desorden». Ante ello, Cordones habría contestado "que el no era Soldado Veterano y que haria lo que le diese la gana», y que si querían que actuara de modo distinto «le pusiesen la casaca» y lo «acuartelaran». Según relata Manuel Campus, en el oficio enviado al fiscal que instruyó un sumario a partir de los hechos, Cordones fue detenido por la fuerza y enviado a la prevención para evitar «el mal ejemplo a las demás compañías». Este habría intentado resistir, increpó a su jefe por ser «portugués» y acusó al gobierno de «pícaro», por haberlo «nombrarlo jefe de Americanos» (CNAA, 1994: 144-145).

Horas después, estando Campus en el fuerte de San José, se le acercó el teniente Juan Ponce a expresarle que toda la compañía de cazadores pedía por la libertad de Cordones. A Ponce se le sumaron los soldados Apolinairo Gayoso y Domingo Torreyro señalando que si no se ponía de forma inmediata en libertad a Cordones «ellos quedarían presos junto con el», generando «corrillos» y poniéndose a la cabeza de un grupo que marchó «en gran murmullo» hasta la Plaza Mayor y se concentró frente al cabildo. Los hechos siguientes

\footnotetext{
${ }^{26}$ Los expedientes judiciales que aquí se analizan se encuentran éditos en CNAA, 1994, 132-149). Habían sido publicados de manera fragmentaria por el historiador Agustín Beraza en el año 1959 (Beraza, Agustín, «Sumarios militares de la Patria Vieja, 1815, en Estado Mayor del Ejército, Boletín Histórico 80-83 (1959): 64-77) y algunos aspectos de su contenido fueron referidos en un trabajo de la historiadora Ana Frega publicado en 1996 (Frega, 1996, 149-171.) y en un texto reciente de Pablo Ferreira (2017, 10-23).
} 
resultan confusos; de las distintas declaraciones sabemos que Campus y sus ayudantes se dirigieron al cabildo y advirtieron a los cívicos reunidos «que lo mejor que podían hacer era retirarse». El episodio se cerró con la mediación del cuerpo capitular y con la detención de algunos milicianos (CNAA 1994: 146).

A los implicados se les instruyó una sumaria «acusados de insubordinación y simentadores de este delito en toda la Compañía». A Torreyro y Gayoso se los acusó de ser «cavezas de motín, p.a pedir la libertad de Cordones» y a este último «por la falta de respeto que tubo a la lista» y por ser «el motor del desorden» que se notaba en la compañía (CNAA 1994: 144-145). El asesor del Cabildo, Francisco Llambí, quien recibió el expediente después de las primeras actuaciones expuso que según las ordenanzas correspondía a los amotinados la «pena capital», pero agregó que tratándose de «una milicia urbana», que no tenía «declarado el fuero» y a cuyos integrantes «solo se les considera como unos vecinos dedicados al beneficio del pais», era suficiente castigo la prisión que habían sufrido. Debían dar una satisfacción al sargento mayor y ser apercibidos, para lo sucesivo, de que recibirían el más severo castigo. A los atenuantes se agregaba el hecho de que las tropas veteranas habían cometido «crímenes de mayor enormidad, sin q.e se les haya impuesto el menor castigo». Finalmente, expuso que la aplicación de penas más graves «causaria en lo gral del pueblo zelos y resentimientos» que «acarrearian graves perjuicios» (CNAA 1994: 150-151).

El expediente incluía otras acusaciones contra Masariego, Cordones y también contra un joven miliciano de origen inglés y de apellido Gowlan, por expresiones contrarias al gobierno. Según relató un testigo, la noche anterior a los sucesos descriptos, conversaban en la guardia los dos primeros y el comandante Juan José Maza, expresándose Cordones molesto con «el Portugués q.e nos quiere amolar», haciendo referencia al sargento Campus Silba. ${ }^{27}$ El otro soldado, Masariego, se habría mostrado de acuerdo añadiendo que en el gobierno eran «unos picaros desde el primero hasta el último». Finalmente, el sargento Maza habría agregado que a los integrantes del gobierno había que «dejarlos gozar del sol mientras dura» (CNAA, 1994: 134-135).

Del conjunto del documento emerge con nitidez el rechazo a las pretensiones de disciplinar a estos cuerpos integrados por vecinos, que se sienten eximidos de obligaciones que consideran propias de la tropa veterana. Al mismo tiempo, los expedientes permiten apreciar aristas de la conflictividad política, acercan algunas trazas de la compleja relación

\footnotetext{
${ }^{27}$ La referencia despectiva al sargento mayor en función de su origen portugués debe entenderse teniendo en cuenta que la banda oriental era un territorio fronterizo entre las posesiones de las coronas españolas y lusitanas. En 1811 los lusitanos habían invadido en apoyo de los leales montevideanos, permaneciendo hasta 1812. En 1815 se extendían los temores sobre una expedición española que contaría con apoyo lusitano, en un escenario político global marcado por el consenso restauracionista de las monarquías europeas.
} 
entre los oficiales elegidos, las planas veteranas y los milicianos, y hacen posible apreciar la continuidad entre diversos espacios de la vida política en la ciudad. El conflicto surgía en la milicia pero la superaba rápidamente y tomaba el espacio público, ubicándose en la plaza, el escenario principal de sociabilidad de la ciudad. En tal sentido, muestra a la milicia como un espacio de acción política de fronteras porosas y de intensas relaciones con los demás lugares de la política montevideana.

En la madrugada del 3 de setiembre de 1816 se produjo un fallido intento de revolución que tuvo como protagonistas a las milicias cívicas. ${ }^{28}$ Con el trasfondo de la invasión lusitana que avanzaba sobre Montevideo, los participantes del levantamiento (sectores de la notabilidades urbanas y la milicia cívica) se hicieron de forma efímera con el poder, tomando prisionero a la máxima autoridad política y militar de la ciudad, el delegado artiguista Miguel Barreiro, a varios integrantes del Cabildo y a otros funcionarios de gobierno.

A primera hora de la mañana fueron llamados «uno a uno» los demás integrantes del Cabildo y ante la presencia de numerosos «ciud.nos [que] ocupaban la Plaza», los instaron a convocar por bando al conjunto del «pueblo patriota» para «explicar su voluntad, y prestar sobre ella sus sufragios» (CNAA 1998b: 228). A las nueve de la mañana se realizó una reunión de vecinos en el cabildo que resolvió solicitar «reasumiese la corporación el gob.no politico y militar de la Prov.a» que unas semanas antes había quedado simplificado en manos del delegado y el regidor Joaquín Suárez (CNAA 1998b: 229-230). El acta de la reunión fue firmada por muchas figuras de reconocida actuación política anterior.

Sin embargo, entre la tarde y noche de ese día la correlación de fuerzas cambió. La reacción favorable al delegado Miguel Barreiro, tuvo un claro protagonismo de los regimientos de morenos, del cuerpo de artillería y de las fuerzas de caballería de la provincia ubicadas en extramuros de la ciudad. Según señala Felipe Duarte, comandante de las fuerzas de caballería de la Provincia, en la «sobretarde» del mismo día tres habría logrado con sus tropas liberar a Barreiro que estaba preso en el cabildo y llevarlo a la Ciudadela donde habían fuerzas no plegadas a la conjura (CNAA 1998b: 234). A su vez, la tropa de artillería comandada por Manuel Oribe habría rescatado a su comandante Bonifacio Ramos. Por momentos se

\footnotetext{
${ }^{28}$ Sobre el episodio véase Reyes Abadie, Washington, Bruschera, Oscar y Melogno, Tabaré, El Ciclo Artiguista, tomo IV, (Montevideo, Ediciones de la Banda Oriental, 1968), pp. 101-105y Ferreira, «Ciudadanos en armas...». Utilizamos para este caso el concepto de revolución en el sentido que asigna la historiadora Hilda Sabato (2006: 278) al sostener que «las revoluciones no se concebían como ruptura sino como restauración del orden violado por el tirano de turno. Y formaban parte del repertorio de prácticas políticas consideradas legítimas por varias generaciones» durante el siglo XIX. Para una reflexión sobre los distintos sentidos asignados a la voz «revolución» en el siglo XIX, véase Wasserman (2014).
} 
temió un enfrentamiento armado entre los integrantes de la infantería y la caballería cívica que participaban de la rebelión, y los cuerpos de artillería y de morenos que respaldaban al gobierno, pero finalmente las milicias se dispersaron y los principales líderes fueron hechos prisioneros y otros lograron escapar a Buenos Aires.

La participación política de los grupos afrodescendientes en el proceso revolucionario hispanoamericano está siendo revisada ampliamente por la historiografía. ${ }^{29}$ Desde el inicio de la revolución se habían formado cuerpos de pardos y morenos libres, al tiempo que se había propiciado la fuga de esclavizados bajo la promesa de obtener la libertad a cambio de la incorporación a los ejércitos revolucionarios (Frega 2004: 50). Durante la etapa de gobierno oriental se formaron compañías de morenos libres integradas al regimiento de dragones de la libertad y se reclutó un contingente que cumplió tareas en la maestranza de artillería. En carta dirigida al gobernador Miguel Barreiro de julio de 1816, Artigas ordenaba fortalecer el cuerpo de artillería con más morenos libres a los que consideraba «buenos soldados y de confianza» y sugería «armarlos de fusiles» (CNAA,1987:244). El 25 de agosto Barreiro escribía al regidor Joaquín Suárez informándole que en proporción de los esclavizados que tenía cada vecino les había «sacado» un cierto número para formar un batallón de milicias. Este contingente cumplió un papel fundamental para sostener a las autoridades artiguistas durante la revolución de los cívicos. Como ha señalado el historiador Alex Borucki (154), la primera acción del flamante batallón no fue luchar contra los portugueses sino reprimir una insurrección de las elites.

Por el contexto crítico en que se produjo, así como por los vínculos externos a la ciudad que tenía el levantamiento cívico, se trató del episodio de movilización miliciana más importante del período. Condensó motivaciones diversas que iban desde posibles alianzas políticas con otros poderes de región, el rechazo a una eventual salida de los cuerpos milicianos a combatir fuera de la ciudad, las críticas a la concentración del poder en el delegado artiguista y a la formación de contingentes integrados por esclavizados para la defensa de la plaza.

El episodio es ilustrativo de una abigarrada trama de intereses y temores que confluyeron en la coyuntura. Los rechazos que generaba el radicalismo artiguista, la perspectiva de una nueva guerra y sus efectos sobre el orden social, las expectativas que despertaba el avance lusitano o las posibilidades de una reconciliación con el gobierno directorial, ubicaron a una parte importante de los notables montevideanos en oposición al

\footnotetext{
${ }^{29}$ Una visión panorámica en Lasso, Marixa, «Los grupos populares y la independencia: cun nuevo paradigma historiográfico?» en Thibaud, Clément, Entin, Gabriel, Gómez, Alejandro y Morelli, Federico (dir.) L'Atlantique révolutionnaire. Une perspective ibéro-américaine, (París, Les Perséides Editions, 2013): 373-394.
} 
gobierno oriental. Las milicias cívicas, por la extracción social de sus mandos y en tanto contingentes en armas, se convirtieron en uno de los instrumentos con que contaron los notables locales para lograr incidir en los destinos políticos de la Provincia.

\section{Diálogos posibles}

En este apartado proponemos poner en diálogo algunos de estos episodios partiendo de la premisa de que los tumultos, los motines y las prácticas conspirativas integraron el repertorio de modalidades de acción contestataria que utilizaron, en coyunturas y por motivaciones diversas, los sujetos políticos del período, tanto los grupos de notables como las clases populares.

Motines, tumultos y conspiraciones fueron términos de amplio uso e inscriptos en la cultura jurídica y política de la monarquía hispánica. Según el Diccionario de Autoridades publicados entre 1726 y 1739 un motín era definido como un «Tumulto, movimiento o levantamiento del Pueblo o otra multitud contra sus cabezas y Xefes». Un tumulto, en tanto, remitía a un «motín, alboroto, confusión popular, o Militar, que conspira contra su superior» y como un «concurso grande de gente que causa desorden o inquietud». Finalmente, una conspiración era definida como la «unión de muchos o algunos contra el Soberano, República o particular».30 Como vemos, los sentidos de estas prácticas se superponían y tenían en común la idea de un «levantamiento» contra los que mandaban. El significado incorporado en ediciones posteriores para la voz «motín», en tanto, agregaba la idea de que la ruptura con las autoridades podía tener por fundamento el no cumplimiento de alguna obligación o el menoscabo de un derecho. ${ }^{31}$

En los episodios reseñados, los motivos para justificar las acciones contestatarias estuvieron vinculados a la idea de derechos, usos o costumbres vulnerados por las autoridades. En julio de 1810, los integrantes de los regimientos de Infantería Ligera y de Voluntarios del Río de la Plata se amotinaron aduciendo que se sentían agraviados por el desembarco de la marina y el llamado a otros cuerpos de milicias a las armas, lo que consideraban vulneraba sus prerrogativas. En julio de 1815, la movilización de los cívicos tuvo su origen en los desórdenes que se generaron al pasar revista y a la reprimenda del sargento mayor al principal involucrado, que fue leída como un intento de tratar a las milicias al modo de la tropa veterana. Por su parte uno de los principales motivos para el levantamiento de los cívicos en 1816 fue la pretensión del gobierno de llevarlos a combatir

\footnotetext{
${ }^{30}$ Real Academia Española, Diccionario de Autoridades, Varios tomos, 1726-1739.

${ }^{31}$ Real Academia Española, Diccionario de la lengua castellana compuesto por la Real Academia Española. (Madrid, Viuda de Ibarra, 1803): 571.
} 
fuera de la ciudad, hecho que iba contra la tradición y las ordenanzas de los cuerpos urbanos, de la que los cívicos se consideraban herederos.

Los episodios trabajados permiten observar lo poroso de las fronteras entre la milicia, los círculos y espacios de sociabilidad de las notabilidades, las esferas de gobierno y el mundo plebeyo. Los milicianos no eran tropa veterana, realizaban un servicio estacional en sus cuerpos y volvían a sus tareas habituales, a sus hogares y a sus círculos de pertenencia habitual. Los encuentros en la milicia prolongaban intercambios y discusiones que se daban en otros ámbitos, a la vez que los potenciaban; vinculando a grupos y personas separadas por barreras geográficas y sociales bajo una misma identidad de cuerpo. En 1810, el motín de la guarnición militar fue el corolario de un enfrentamiento a nivel de las notabilidades (con prolongaciones en el mundo plebeyo) que dividió de manera radical, desde el mes de mayo a los partidarios del reconocimiento de la junta instalada en Buenos Aires con los que se mostraron afines al Consejo de Regencia. Desde ese momento todo fue, según algunos protagonistas, «exaltación, furor y engaños» y se extendió entre la población un «clima de turbaciones y enemistades» estimulado por las autoridades (Mañé 171). El motín del 12 de julio fue la continuidad (y en parte el desenlace armado) de ese enfrentamiento.

Si analizamos el motín de junio de 1814 también podemos observar esa continuidad. Había fuertes divisiones al interior del fidelismo montevideano que se habían visto exacerbadas por el accionar del «partido empecinado», un agrupamiento de carácter político que se caracterizó por una lealtad radical y exaltada, así como por la ejecución de un conjunto de acciones tendientes a hostigar a sus enemigos y a influir, sobre la base de la movilización en el espacio público, sobre las autoridades (Ferreira 2016b: 53). Las acciones empecinadas, en un contexto de deterioro radical y abrupto de las condiciones materiales de existencia, habían ido en incremento las semanas previas al motín. Las negociaciones para la rendición de la ciudad, lejos de tramitarse en la esfera de gobierno, debieron llevarse a instancias más o menos representativas de la ciudad (por ejemplo, juntas de guerras mixtas) y el debate se prolongó en el espacio público. Ello rompía el tradicional «carácter reservado de las cuestiones de gobierno», propio del orden colonial (Serulnikov 31).

En 1816, por su parte, el levantamiento de los cívicos implicó una trama conspirativa en la que participaron importantes sectores de las notabilidades locales. La radicalización del programa social del artiguismo, sumada a los temores que generaba la invasión lusitana, fueron el escenario propicio para que se gestaran acciones orientadas a intentar hacerse del control de la ciudad. La milicia fue la prolongación de un accionar opositor que se había iniciado entre las notabilidades, en las reuniones de comerciantes, en tertulias en casas particulares y en otros espacios de sociabilidad de la ciudad. 
Los cuatro episodios, más allá de las diferencias de contexto y motivos pueden leerse a partir de un cierto patrón o secuencia que, con algunas variantes, se repite. En primer lugar una fase de gestación, donde se destaca la impronta conspirativa, caracterizada por la circulación de noticias y la propagación de rumores, las tertulias y las conversaciones en ámbitos privados o incluso en algunos espacios de sociabilidad. $3^{2}$ Esta fase concluía en el estallido del motín o en la elaboración de alguna suerte de plan de operaciones. Para los historiadores, se trata de un proceso opaco ya que suelen ser escasos los registros en las fuentes, más allá de lo consignado en algunas memorias o en expedientes judiciales levantados con posterioridad. Aun así, leyendo las fuentes de forma crítica, a contrapelo, algunos de estos elementos aparecen. La propagación de rumores, que como han señalado adecuadamente los historiadores Arlette Farge y Jacques Revel (111) traducían y «crea[ba]n convicciones socialmente compartidas », antecedió habitualmente a estos episodios. En 1814, la presunción de que se estaba acordando una rendición vergonzosa y de estar bajo el mando de jefes sin «valentía», fue la traducción de un conjunto de valores que pueden asociarse a una cultura del honor y a una forma de masculinidad que reivindicó el ejercicio de la violencia como factor constitutivo (Johnson 103). En 1816 también circularon diversos rumores, muchos de ellos con una base veraz, pero que crecían en la medida en que iban pasando de persona a persona. La suposición de que la milicia iba a ser obligada a salir a combatir, que la ciudad quedaría bajo la protección de los esclavizados, que se iban a tomar los dineros de los capitalistas, que los orientales abandonarían la ciudad y que los directoriales podrían estar dispuestos a protegerla, entre otras ideas que por entonces circularon, denotan los temores y angustias del momento.

Estos rumores se propagaban a través de reuniones, tertulias y distintas instancias donde iba tomando forma la posibilidad de una acción contestataria. Para cada uno de los episodios analizados encontramos fuentes que señalan la existencia de este tipo de encuentros que luego se trasladaron al interior de los cuerpos milicianos. En este punto coincidimos con los planteos del historiador español Juan Luis Simal, quien ha destacado como la práctica conspirativa y los temores asociados a ella fueron un «un elemento articulador de las dinámicas ideológicas surgidas de la relación entre revolución y contrarrevolución», al tiempo que actuaron como «promotores del faccionalismo entre los revolucionarios» (2018: 527). En 1810 el comandante José María Salazar señalaba en un oficio al marqués de Casa Irujo que los principales oficiales de los cuerpos amotinados

\footnotetext{
${ }^{32}$ Sobre las formas de circulación de la información y la importancia de los rumores véase Guerra, FrançoisXavier, Modernidad e independencias. Ensayos sobre las revoluciones hispánicas. (Madrid, Mapfre, 1992) y Darnton, Robert, El diablo en el agua bendita o el arte de la calumnia de Luis XIV a Napoleón. (Ciudad de México, Fondo de Cultura Económica, 2008).
} 
habían ido celebrando «juntas nocturnas» en las semanas previas donde fueron ganando a oficiales subalternos y particulares (MD, 1965b: 207). En 1814 el estado de movilización ante las propuestas de capitulación era permanente y los encuentros y discusiones se dieron en distintos espacios. Como las milicias urbanas estaban acuarteladas (aunque no aisladas), la posibilidad de estos encuentros se incrementaba. Si avanzamos a 1815, las declaraciones incluidas en el expediente sumarial permiten apreciar las conversaciones que se daban en las guardias, los rechazos que generaba el comandante por su origen portugués, la presencia de personas externas a la milicia que llegaban a conversar con los milicianos, entre otros elementos que denotan la porosidad de estos espacios de sociabilidad. En 1816, lo masivo del levantamiento de los cuerpos cívicos denota la existencia de una trama conspirativa bastante extendida. Carlos Anaya, protagonista de los hechos, refiere en unos apuntes históricos elaborados años después, a un «eco general» de descontento que se propagó en distintos ámbitos de la ciudad durante los días previos (1954: 340). El análisis de los nombres de quienes dirigieron el movimiento permite identificar vínculos que ligarían espacios institucionales (como el Cabildo o la Junta de Comerciantes), redes familiares, grupos de emigrados y finalmente la obtención de los apoyos necesarios en los mandos de los distintos cuerpos milicianos.

Los episodios dialogan también a partir de lo que podríamos identificar como una geografía de la movilización. Podríamos trazar una línea que uniría al Fuerte de San José con la Plaza Mayor (a la que daban el Cabildo y la iglesia Matriz) y el bastión de la Ciudadela. Si pensamos en los cuatro episodios que venimos comentando, todos transcurren a lo largo de ese eje espacial. Los principales hechos de 1810 transcurren en las tres cuadras que van desde la Plaza Mayor hasta la Ciudadela y lo mismo sucede respecto a los hechos de 1814. El episodio de 1815 tiene su origen en las inmediaciones del Fuerte y luego los participantes del tumulto se trasladan a la plaza, donde se desarrolla la protesta frente al Cabildo. Los episodios de setiembre de 1816, más extendidos en el tiempo y el espacio, ocupan todo el eje mencionado.

Otro aspecto que apreciamos al poner en diálogo estos episodios es la cuestión de los liderazgos y los mediadores políticos. En 1810 el levantamiento se personifica en los comandantes de los regimientos, Prudencia Murguiondo y Juan Balvín Vallejo. La movilización fidelista que se les opuso tuvo como figuras claves a los mandos de la Armada (en especial el comandante José María Salazar) y a las milicias urbanas, siendo destacado el papel que tuvo el «grupo de Ponce», a los que luego se denominará como los «empecinados». En 1814, José Neyra, jefe que lidera el motín, resulta una figura bien interesante. Proveniente de Galicia, se había instalado como comerciante en Buenos Aires y había 
emigrado en 1810 por razones políticas. Con su capital se instaló en Montevideo y armó un regimiento miliciano que fue llamado como «Emigrados de Buenos Aires» y que estuvo en actividad hasta el motín analizado. Partió luego a Río de Janeiro, retornó a la ciudad en 1820 y tuvo actuación política hasta el año 1843 en que murió liderando una guerrilla durante la Guerra Grande.33 El levantamiento de los cuerpos cívicos integró en su dirección a notables locales (tal el caso de los comerciantes y abogados Juan María Pérez y Lucas Obes) con mandos milicianos (Prudencio Murguiondo y su hijo Agustín). La asociación de los cuerpos milicianos con los nombres de sus jefes evidencia la fuerte impronta personal del mando. Esto no debe, sin embargo, llevarnos a suscribir sin precauciones analíticas la hipótesis de que estas movilizaciones fueron solamente reflejos de la agenda política de las elites. Las milicias no estuvieron integradas únicamente por sus mandos, sino que articularon una compleja red que incluyó a diversos sectores de la sociedad. Alvaro Paris Martin (89), en esa línea, ha puesto de relieve como los grupos subalternos no fueron "sencillamente movilizados» por las elites, sino que negociaron su participación. Divididos internamente, actuaron con pragmatismo, aprovechando las circunstancias para defender intereses locales y de grupo.

Finalmente, un último aspecto tiene que ver con las sucesivas derrotas de los amotinados en los episodios aquí referidos. Ninguno de los levantamientos triunfó o logró establecer condiciones. En el mejor de los escenarios alcanzaron a pactar su rendición. La derrota de estas movilizaciones es ilustrativa de las escasas posibilidades que tenían estas acciones si no contaban con alianzas más amplias. Es posible pensar también que en varios de los casos analizados no existía un plan de triunfo, sino principalmente la necesidad de marcar una disconformidad ante una situación que se consideraba injusta.

\section{Conclusiones}

La milicia fue fundamental en la organización del sistema defensivo colonial en Hispanoamérica, perduró y se transformó durante los años de la revolución y las guerras de independencia y resultó clave en las primeras décadas de los estados independientes. Pasó de estar conformada por «vecinos en armas» en defensa del rey y sus posesiones, a estar integrada por ciudadanos con el derecho y el deber de defender la República.34 Pasó de ser

\footnotetext{
${ }^{33}$ Sobre José Neyra véase la certificación de sus méritos elaborada por el Cabildo de Montevideo en diciembre de 1813: «Acuerdos del Cabildo de Montevideo, 23 de diciembre de 1813» en RAGA XI, (1919): 229 y el «Certificado de Méritos de José Neyra elaborado por Jacinto Acuña de Figueroa, Montevideo 15 de setiembre de 1821», AGN, Colección de documentos originales sobre historia del Uruguay que pertenecieron al Prof. Juan E. Pivel Devoto, caja 2, carpeta 7, f. 59 .

${ }^{34}$ No referimos en este punto a la voz República en el sentido antiguo, como una comunidad política que actuaba como cuerpo en y que podía hacerlo en el marco de la monarquía, sino en el sentido moderno, como una forma de gobierno opuesta a la monarquía. Sobre la pluralidad de estos sentidos véase Lomné, Georges, «De
} 
una institución organizada en torno a la desigualdad de derechos y deberes propia de la sociedad colonial a una institución basada en el principio republicano de la igualdad ante la ley. La dimensión territorial de la institución explicó en buena medida su adaptabilidad. La defensa del rey no se hacía en tanto súbditos individuales de la monarquía, sino que estaba mediada por la pertenencia a un cuerpo político territorial: la ciudad. La convocatoria durante los gobiernos revolucionarios, en la fase luso-brasileña y en los inicios de la etapa republicana también tuvo una dimensión territorial, fuera esta urbana o departamental.

El derecho y la obligación de «armarse en defensa de la patria» constituyó una dimensión clave de la relación entre pueblo y política en el siglo XIX (Sabato 2010: 59). La socialización política que se generaba en estos cuerpos, las distintas formas de elección de los mandos o la participación en acciones colectivas fueron experiencias políticas de impacto en la construcción de identidades. La milicia generó liderazgos y debió apoyarse en los existentes, en una lógica de negociaciones y pactos entre las autoridades y la población. Fue, en definitiva, una de las instituciones que estructuró y ordenó a la sociedad montevideana.

En el transcurso del artículo se analizaron algunas modalidades de acción contestataria que formaron parte del repertorio de intervención de los contingentes en armas y, por tanto, se fueron convirtiendo en elementos constitutivos de su cultura política. Referimos a los tumultos, los motines en cuarteles o guarniciones, o a los movimientos conspirativos. Las fronteras entre estas diversas formas de acción fueron porosas si nos remitimos al lenguaje de la época y sus significados muchas veces se superpusieron. En varios episodios reseñados, los motivos esgrimidos para justificar la protesta estuvieron vinculados a la idea de derechos o costumbres vulneradas por las autoridades.

En síntesis, tumultos, motines y conspiraciones, acciones colectivas orientadas a influir en el espacio político eran prácticas antiguas. En una coyuntura de cambios radicales y transformaciones políticas integraron el repertorio de aquellos grupos que tuvieron la necesidad de hacer sentir su disconformidad ante las autoridades. No como proyección de un orden nuevo, pero sí como reclamo de derechos vulnerados por quienes ejercían el poder. En tal sentido fueron experiencias disruptivas del orden, provocadoras y desafiantes que ameritan un análisis profundo para entender la vida política del período.

la República y otras repúblicas: La regeneración de un concepto» en Fernández Sebastián, Javier (Dir.), Diccionario político y social del mundo iberoamericano. La era de las revoluciones, 1750-1850, (Madrid, Fundación Carolina, Sociedad Estatal de Conmemoraciones Culturales, Centro de Estudios Políticos y Constitucionales, 2009): 1253-1269 


\section{Anexo \\ Plano de la ciudad de Montevideo elaborado por José del Pozo y Maqui, 15 de marzo de 181235}

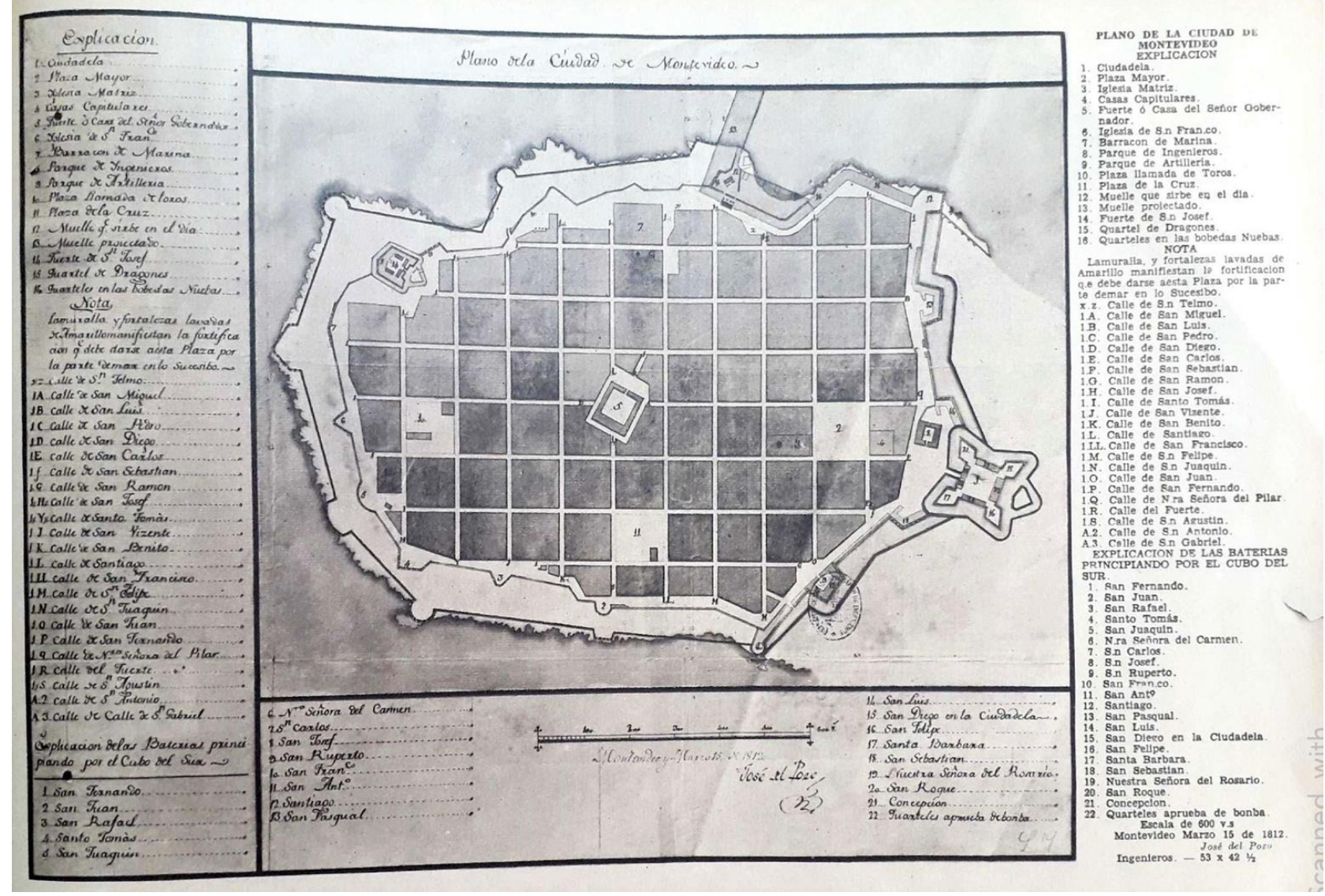

\section{Obras citadas}

\section{Fuentes editadas}

Acuña de Figueroa, Francisco, Diario Histórico del Sitio de Montevideo en los años 1812-13-14, Tomos I y II, Biblioteca Artigas, Colección Clásicos Uruguayos Vol.157-158. (Montevideo: 1978).

Archivo General de la Nación, Revista del Archivo General Administrativo o Colección de documentos para servir al estudio de la Historia de la República Oriental del Uruguay (RAGA), tomos 6 y 9 (Montevideo: Dornaleche Hnos.,1917, 1919).

Comisión Nacional Archivo Artigas (CNAA). Archivo Artigas, Montevideo, tomos VII (1966), XVI (1978), XXI (1987), XXIV (1991), XXVIII (1994), XXX (1998), XXXI (1998b), Montevideo.

Real Academia Española (RAE), Diccionario de Autoridades, Tomo IV, (1734).

- Diccionario de la lengua castellana compuesto por la Real Academia Española. (Madrid, Viuda de Ibarra, 1803)

Universidad de Buenos Aires, Facultad de Filosofía y Letras, Instituto de Historia Argentina «Dr. E. Ravignani», Mayo documental (MD), t. XI y XII tomos, (Buenos Aires, Talleres Gráficos Guillermo Kraft Ltda., 1965a y 1965b).

\footnotetext{
${ }^{35}$ Tomado de Travieso, Carlos, Montevideo en la época colonial. Su evolución a través de mapas y planos españoles, (Montevideo, 1937): 73.
} 


\section{Bibliografías}

Aguerre, Fernando, Los últimos españoles. Autonomía y lealtad a la Corona en el Montevideo insurgente (1802-1815). (Montevideo, Linardi y Risso, 2011).

Alemano, María Eugenia. «Soldados de Pinazo. El poder miliciano en el norte de la frontera de Buenos Aires (1776-1779)» en Barriera, Darío y Fradkin, Raúl (coords.), Gobierno, justicias y milicias: la frontera entre Buenos Aires y Santa Fe (La Plata, FaHCE, 2014): 177-209.

Anaya, Carlos. «Apuntaciones históricas sobre la Revolución Oriental (1811-1851)», en Revista Histórica. 20 (1954): 263-412.

Barrán, José Pedro. «La independencia y el miedo a la revolución social», en Revista de la Biblioteca Nacional 24, (1986): 65-77.

Bauzá, Francisco, Historia de la Dominación Española en el Uruguay, Tres tomos, $3 .^{\text {a }}$ ed., (Montevideo: Palacio del Libro, 1929).

Bentancur, Arturo. El puerto colonial de Montevideo, tomo 2. (Montevideo, FHCE, Universidad de la República, 1999).

Beraza, Agustín. El pueblo reunido y armado. (Montevideo, Ediciones de la Banda Oriental, 1967).

Beverina, Juan. El Virreinato de las Provincias del Río de la Plata. Su organización militar. (Buenos Aires, Círculo Militar, 1935).

Birolo, Pablo. Militarización y Política en el Río de la Plata Colonial. Cevallos y las campañas militares contra los portugueses, 17569-1778, (Buenos Aires, Prometeo, 2014).

Blanco Acevedo, Pablo. El Gobierno Colonial en el Uruguay y los orígenes de la Nacionalidad, Tomo II, Biblioteca Artigas, Colección de Clásicos Uruguayos, Volumen 150. (Montevideo, Barreiro y Ramos, 1975).

Borucki, Alex. De compañeros de barco a camaradas de armas. Identidades negras en el Río de la Plata, 1760-1860, Montevideo, Prometeo, 2017.

Cansanello, Orestes. De Súbditos a Ciudadanos. Ensayo sobre las libertades en los orígenes republicanos, Buenos Aires, 1810-1852. (Buenos Aires, Imago Mundi, 2003).

Carrot, Georges. La Garde nationales (1789-1871), Une force politique ambiguë, (París, L' Harmat$\tan , 2001)$.

Chust, Manuel y Marchena, Juan. «De milicianos de la Monarquía a guardianes de la Nación» en Manuel Chust, Juan Marchena, Las armas de la nación: independencia y ciudadanía en Hispanoamérica (1750-1850), Madrid, Iberoamericana, Verveut, 2007, pp. 7-14.

- y José Serrano. «Milicia y revolución liberal en España y en México» en Chust, Manuel y Marchena, Juan, Las armas de la Nación. Independencia y ciudadanía en Hispanoamérica (1750-1850), Madrid, Iberoamericana, 2007, pp. 81-110. Las notas en el texto corresponden a la versión digital disponible en http://historiapolitica.com/datos/biblioteca/chustserrano.pdf.

Chiaramonte, José Carlos. «Acerca del origen del Estado en el Río de la Plata», en Anuario IEHS, 10 (1995), 27-50.

Darnton, Robert. El diablo en el agua bendita o el arte de la calumnia de Luis XIV a Napoleón. (Ciudad de México, Fondo de Cultura Económica, 2008).

Di Meglio, Gabriel. iViva el bajo pueblo! La plebe urbana de Buenos Aires y la política entre la Revolución de Mayo y el rosismo (1810-1829). (Buenos Aires, Prometeo Libros, 2007).

- «Las palabras de Manul. La plebe porteña y la política en los años revolucionarios» en Fradkin, Raúl O. (ed.) ¿Y el pueblo dónde está? Contribuciones para una historia popular de la revolución de independencia en el Río de la Plata, (Buenos Aires, Prometeo, 2008): 67106.

Dupuy, Roger. «La Garde nationale: du déni historiograpique à la necessité dún nouveau questionnement», en Bianchi, Serge y Dupuy, Roger (dir), La Garde nationale entre Nation et peuple 
en armes: Mythes et réalités, 1789-1871, (Rennes, Presses Universitaires de Rennes, 2016): $15-24$.

Etchechury, Mario. «Regularizar la guerra, disciplinar la sociedad. Una nota sobre el reclutamiento de fuerzas de guerra mercenarias durante la última etapa de la Guerra Grande» en Garavaglia, Juan Carlos, Pro Ruiz, Juan y Zimmermann, Eduardo (edit.), Las fuerzas de la guerra en la construcción del Estado. América Latina, siglo XIX, (Rosario, Prohistoria, 2012): 287-318.

- $\quad$ «De colonos y súbditos extranjeros a 'ciudadanos en armas'. Militarización y lealtades políticas de los españoles residentes en Montevideo, 1838-1845” en Revista Universitaria de Historia Militar 8 (2015):119-142.

Farge, Arlette y Revel, Jacques. Lógica de las multitudes. Secuestro infantil en París, 1750, Rosario, Homo Sapiens Ediciones, 1998.

Ferreira, Pablo. «Los amotinados de la Matriz. Una aproximación al estudio del conflicto social y político en el ocaso del Poder Español en Montevideo» en Avances de Investigación (Montevideo, FHCE, Universidad de la República, 2013): 23-42.

- «Ciudadanos en armas. La experiencia de la milicia cívica en Montevideo, 1815-1817» en Claves. Revista de Historia 2, (2016a): 9-45.

- «La guerra de independencia española, los empecinados y el Montevideo leal, 1808-1814.» en Pasado Abierto 4, (2016b): 41-6o.

- «QQue se vaya la Patria al ajo..." El año XV, las milicias cívicas y los espacios de resistencia al poder artiguista en Montevideo» en Revista Historia para todos 5 (2017): 10-23.

- «La rendición de Montevideo y el motín de la Matriz en junio de 1814» en Frega, Ana (Coord.), La vida política en Montevideo: elites y sectores populares en tiempos de revolución. (Montevideo, CSIC, Universidad de la República, 2018): 45-75.

- y Ana Frega. «Leales españoles, orientales y porteños en Montevideo en 1814», en O’Phelan, Scarlett (Coord.), 1814: La junta de gobierno del Cuzco y el sur andino, Lima, Fondo Editorial PUC, IFEA, Fundación M. J. Bustamante de la Fuente, 2016, pp. 15-25.

Fessler, Daniel. «Desertores: entre el castigo y el indulto» en Frega, Ana (Coord.), Los orientales en armas. Estudios sobre la experiencia militar en la revolución artiguista, (Montevideo, CSIC, Universidad de la República, 2015): 29-54.

Fradkin, Raúl. «Tradiciones militares coloniales. El Río de la Plata antes de la revolución», en Heinz, Flavio (Comp.), Experiências nacionais, temas trasnversais: subsídios para uma história comparada da América latina, (Sao Leopoledo, Oikos, 2009): 74-126. Las notas en el texto corresponden a la versión digital disponible en http://historiapolitica.com/dossiers/lasguerras/

- «Cultura política y acción colectiva en Buenos Aires (1806-1829): un ejercicio de exploración», Fradkin, Raúl, (Ed.) ¿Y el pueblo dónde está? Contribuciones para una historia popular de la revolución de independencia en el Río de la Plata. (Buenos Aires, Prometeo, 2008): 27-65.

Frega, Ana. «La dimensión de lo privado en tiempos revolucionarios» en Barrán, José Pedro, Caetano, Gerardo y Porzecanski, Teresa, Historias de la vida privada en el Uruguay. Entre la honra y el desorden. 1780-1870. (Montevideo, Taurus, 1996): 148-171.

- «La virtud y el poder. La soberanía particular de los pueblos en el proyecto artiguista», en Goldman, Noemí y Salvatore, Ricardo. Caudillismos rioplatenses. Nuevas miradas a un viejo problema. (Buenos Aires, Eudeba, 1998): 101-133.

- "Caminos de libertad en tiempos de revolución. Los esclavos en la Provincia Oriental artiguista, 1815-1820» en Bentancur, Arturo, Borucki, Alex y Frega, Ana (eds.), Estudios sobre la cultura afro-rioplatense. Historia y presente, (Montevideo, FHCE, Universidad de la República, 2004): 45-66.

- «La Junta de Montevideo de 1808», en Chust, Manuel (coord.). 1808. La eclosión Juntera 
en el Mundo Hispánico. (Ciudad de México, El Colegio de México, Fondo de Cultura Económica, 2007): 242-268.

- Pueblos y soberanía en la revolución artiguista. La región de Santo Domingo Soriano desde fines de la colonia a la ocupación portuguesa, (Montevideo, Ediciones de la Banda Oriental, 2007)

- «El Reglamento de Tierras de 1815: justicia revolucionaria y virtud republicana» en Caetano, Gerardo y Ribeiro, Ana (Coord.), Tierras, Reglamento y revolución. Reflexiones a doscientos años del Reglamento Artiguista de 1815. (Montevideo, Planeta, 2015): 487-532.

- «Revolución y contra-revolución en Montevideo en 1810: el frustrado motín de la guarnición militar» en Frega, Ana (Coord.), La vida política en Montevideo: elites y sectores populares en tiempos de revolución. (Montevideo, CSIC, Universidad de la República, 2018): 17-42.

García Flavio (sel.).«El proceso de gestación de la revolución de los pueblos orientales a través de una selección documental de 1810», en Boletín Histórico del Ejército, 84-87, (1960), 1-383.

Gayol, Víctor. «Las milicias nacionales en la construcción del Estado-Nación en España e Hispanoamérica, siglo XIX: Hacia un balance historiográfico» en Ruiz Ibañez, José Javier (Coord.), Las milicias del rey de España. Sociedad, política e identidad en las Monarquías Ibéricas. (Madrid, Fondo de Cultura Económica, Red Columnaria, 2009): 460-480.

Girard, Luis. La Garde Nationale, 1814-1871. (París, Librarie Plon, 1964).

Guerra, François-Xavier, Modernidad e independencias. Ensayos sobre las revoluciones hispánicas. (Madrid, Mapfre, 1992).

Halperin Donghi, Tulio. «Militarización revolucionaria en Buenos Aires, 1806-1815», en Halperin Donghi, Tulio (Comp.) El ocaso del orden colonial en Hispanoamérica, (Buenos Aires, Sudamericana, 1978): 121-158.

- Revolución y guerra. Formación de una élite dirigente en la Argentina criolla, (Buenos Aires, Siglo Veintiuno Editores, 2014).

Johnson, Lyman. Los talleres de la revolución. La Buenos Aires plebeya y el mundo del Atlántico, 1776-181o, (Buenos Aires, Prometeo, 2013).

Kuethe, Allan. «Las milicias disciplinadas en América», en Kuethe, Allan y Marchena, Juan (eds.), Soldados del Rey. El ejército borbónico en América colonial en vísperas de la independencia, (Castellón. Univesitat Jaume I, 2005): 101-126.

Larrañaga, Dámaso Antonio y José Raymundo Guerra. «Apuntes históricos sobre el descubrimiento y población de la Banda Oriental del Río de la Plata y las ciudades de Montevideo, Maldonado, Colonia, etc.» en Revista Histórica VII, (1914): 81-108.

Lasso, Marixa. «Los grupos populares y la independencia: ¿̇un nuevo paradigma historiográfico?» en Thibaud, Clément, Entin, Gabriel, Gómez, Alejandro y Morelli, Federico (dir.) L'Atlantique révolutionnaire. Une perspective ibéro-américaine, (París, Les Perséides Editions, 2013): 373-394.

Lomné, Georges. «De la República y otras repúblicas: La regeneración de un concepto» en Fernández Sebastián, Javier (Dir.), Diccionario político y social del mundo iberoamericano. La era de las revoluciones, 1750-1850, (Madrid, Fundación Carolina, Sociedad Estatal de Conmemoraciones Culturales, Centro de Estudios Políticos y Constitucionales, 2009): 1253-1269.

Luzuriaga, Juan Carlos. La reconquista de Buenos Aires. El cenit de Montevideo colonial, (Montevideo, Planeta, 2017).

Macías, Flavia. «Ciudadanos armados» y fuerzas militares en la construcción republicana decimonónica», en Senado de la Nación Argentina, Identidad Nacional: hacia la Argentina del Bicentenario. Reflexiones sobre el concepto de ciudadanía, (Buenos Aires, Senado de la Nación, 2010).

Mañé Garzón, Fernando. El glorioso montevideano. Vida y obra de José Manuel Pérez Castellano (1742-1815), (Montevideo, MEC-AGN-Centro de Difusión del Libro, 2003). 
Marchena, Juan. Ejército y milicias en el mundo colonial americano, (Madrid, Mapfre, 1992).

- y Manuel Chust (ed.), Por la fuerza de las armas. Ejército e independencias en Iberoamérica, Colección América 12, (Castellón, Universitat Jaume I, 2008).

Morelli, Federica. «¿Disciplinadas o republicanas? El modelo ilustrado de milicias y su aplicación en los territorios americanos (1750-1826)» en Ruiz Ibáñez, José Javier (coord.), Las milicias del Rey de España. Sociedad, política e identidad en las Monarquías Ibéricas, (Madrid, Fondo de Cultura Económica, Red Columnaria, 2009): 417-436.

Ortiz Escamilla, Juan (coord.). Fuerzas militares en Iberoamérica, siglos XVIII y XIX, (Ciudad de México, El Colegio de México/El Colegio de Michoacán/Universidad Veracruzana, 2005).

Ossa Santa Cruz, Juan Luis. Armies, politics and revolution. Chile, 1808-1826. (Liverpool, Latin American Studies, 2014).

Paris Martin, Álvaro. «Los voluntarios realistas de Madrid. Politización popular y violencia contrarrevolucionaria (1823-1833)» en Rújula, Pedro y Solans, Ramón (eds.), El desafío de la revolución. Reaccionarios, antiliberales y contrarrevolucionarios, (Granada, Comares, 2017): 89-106.

Pérez Garzón, Juan. Milicia nacional y revolución burguesa: el prototipo madrileño, 1808-1874, (Madrid, CSIC, 1978).

Pivel Devoto, Juan, Historia de los Partidos Políticos en el Uruguay, Tomo I, (Montevideo, Claudio García y Cía, 1942).

- Raíces coloniales de la revolución oriental de 1811. (Montevideo, Monteverde, 1952).

- Historia de los partidos y de las ideas políticas en el Uruguay:la definición de los bandos (1829-1838), Montevideo, Ediciones del Río de la Plata, 1956.

- (Comp.), «La Junta Montevideana de 1808», en Revista Histórica XXXIII, (1962): 371-902.

Rabinovich, Alejandro. La société guerrière. Pratiques, discours et valeurs militaires dans le Rio de la Plata, 1806-1852. (Rennes, Presses Universitaires de Rennes, 2013).

Reyes Abadie, Washington, Oscar Bruschera y Tabaré Melogno. El ciclo artiguista, Tomos I y 4, (Montevideo, EBO, 1968).

Ribeiro, Ana.Los muy fieles. Leales a la Corona en el proceso revolucionario rioplatense. Montevideo/Asunción, 1810-1820, t. 2, (Montevideo, Planeta, 2013).

Rilla, José. La actualidad del pasado. Usos de la historia en la política de partidos del Uruguay (1942-1972). (Montevideo, Debate, 2008)

Ruiz Ibáñez, José Javier «Introducción: las milicias del rey de España» en Ruiz Ibañez, José Javier (coord.), Las milicias del Rey de España. Sociedad, política e identidad en las Monarquías Ibéricas, (Madrid, Fondo de Cutlura Económica, Red Columnaria, 2009): 9-38.

Rújula, Pedro. «La densificación del universo político popular durante la guerra de independencia» en Rújula, Pedro y Canal, Jordi (eds.), Guerra de ideas. Política y cultura en la España de la Guerra de la Independencia, (Zaragoza, Instituto Fernando el Católico, 2011): 173-190.

Sabato, Hilda. «La reacción de América: la construcción de las repúblicas en el siglo XIX» en Chartier, Roger y Feros, Antonio (Ed.), Europa, América y el mundo: tiempos históricos, (Madrid, Marcial Pons, 2006): 263-280.

- Pueblo y política. La construcción de la Argentina Moderna, (Buenos Aires, Capital Intelectual, 2010).

- «Los desafíos de la República. Notas sobre la política en la Argentina pos Caseros» en Estudios Sociales, 46 (2014): 77-117.

Sala, Lucía, Julio Rodríguez y Nelson de la Torre. Artigas y su revolución agraria 1811-1820, (Ciudad de México, Siglo Veintiuno Editores, 1987).

Serulnikov, Sergio. «Nuevas formas de hacer política: los sectores plebeyos urbanos y la debacle de la sociedad de indias en el Alto Perú» en Fradkin, Raúl y Di Meglio, Gabriel (Comp.), Hacer 
política. La participación popular en el siglo XIX rioplatense, (Buenos Aires, Prometeo, 2013): $15-47$.

Sobrevilla, Natalia. «De vasallos a ciudadanos: las milicias coloniales y su transformación en un ejército nacional en las guerras de independencia en el Perú» en Mc Evoy, Carmen, Novoa, Mauricio y Palti, Elías (Eds.), El nudo del Imperio. Independencia y democracia en el Perú, (Lima, IFEA, 2012): 251-270.

Thibaud, Clement. Repúblicas en armas. Los ejércitos bolivarianos en la guerra de independencia en Colombia y Venezuela, (Bogotá, Planeta-IFEA, 2003).

Tilly, Charles. «Repertorios de acción contestataria en Gran Bretaña: 1758-1834», en Traugott, Mark (Comp.), Protesta Social. Repertorios y ciclos de la acción colectiva, (Barcelona, Editorial Hacer, 2002).

Wasserman, Fabio. «Argentina/Río de la Plata» en Zermeño, Guillermo (Ed.), Revolución, Tomo II del Diccionario político y social del mundo iberoamericano (Madrid, Universidad del País Vasco, Centro de Estudios políticos y constitucionales, 2014): 49-64. 